\title{
Allanite at high temperature: effect of REE on the thermal behaviour of epidote-group minerals
}

\author{
G. Diego Gatta ${ }^{1}$ (1) . Francesco Pagliaro ${ }^{1} \cdot$ Paolo Lotti $^{1} \cdot$ Alessandro Guastoni $^{2} \cdot$ Laura Cañadillas-Delgado $^{3}$. \\ Oscar Fabelo ${ }^{3}$. Lara Gigli ${ }^{4}$
}

Received: 4 June 2021 / Accepted: 13 July 2021 / Published online: 22 August 2021

(C) The Author(s) 2021

\begin{abstract}
The thermal behaviour of a natural allanite-(Ce) has been investigated up to $1073 \mathrm{~K}$ (at room pressure) by means of in situ synchrotron powder X-ray diffraction and single-crystal neutron diffraction. Allanite preserves its crystallinity up to $1073 \mathrm{~K}$. However, up to $700 \mathrm{~K}$, the thermal behaviour along the three principal crystallographic axes, of the monoclinic $\beta$ angle and of the unit-cell volume follow monotonically increasing trends, which are almost linear. At $T>700-800 \mathrm{~K}$, a drastic change takes place: an inversion of the trend is observed along the $a$ and $b$ axes (more pronounced along $b$ ) and for the monoclinic $\beta$ angle; in contrast, an anomalous increase of the expansion is observed along the $c$ axis, which controls the positive trend experienced by the unit-cell volume at $T>700-800 \mathrm{~K}$. Data collected back to room $T$, after the $\mathrm{H} T$ experiments, show unitcell parameters significantly different with respect to those previously measured at $293 \mathrm{~K}$ : allanite responds with an ideal elastic behaviour up to $700 \mathrm{~K}$, and at $T>700-800 \mathrm{~K}$ its behaviour deviates from the elasticity field. The thermo-elastic behaviour up to $700 \mathrm{~K}$ was modelled with a modified Holland-Powell EoS; for the unit-cell volume, we obtained the following parameters: $V_{\mathrm{T} 0}=467.33(6) \AA^{3}$ and $\alpha_{\mathrm{T} 0}(V)=2.8(3) \times 10^{-5} \mathrm{~K}^{-1}$. The thermal anisotropy, derived on the basis of the axial expansion along the three main crystallographic directions, is the following: $\alpha_{\mathrm{T} 0}(a): \alpha_{\mathrm{T} 0}(b): \alpha_{\mathrm{T} 0}(c)=1.08: 1: 1.36$. The $T$-induced mechanisms, at the atomic scale, are described on the basis of the neutron structure refinements at different temperatures. Evidence of dehydroxylation effect at $T \geq 848 \mathrm{~K}$ are reported. A comparison between the thermal behaviour of allanite, epidote and clinozoisite is carried out.
\end{abstract}

Keywords Allanite $\cdot$ Epidote $\cdot$ Synchrotron powder X-ray diffraction · Single-crystal neutron diffraction $\cdot$ High temperature

\section{Introduction}

Allanite is a sorosilicate, belonging to the epidote group minerals, with general crystal chemical formula $A(1) A(2) M(1) M(2) M(3)\left(\mathrm{SiO}_{4}\right)\left(\mathrm{Si}_{2} \mathrm{O}_{7}\right) \mathrm{O}(\mathrm{OH})$, in which $A(1)$ and $A(2)$ are sites with coordination number $\mathrm{CN}>6$ and mainly occupied by $\mathrm{Ca}$, and $M(1), M(2)$ and $M(3)$ are

G. Diego Gatta

diego.gatta@unimi.it

1 Dipartimento di Scienze della Terra, Università degli Studi di Milano, Via S. Botticelli 23, 20133 Milano, Italy

2 Dipartimento di Geoscienze, Università degli Studi di Padova, Via G. Gradenigo 6, 35131 Padova, Italy

3 Institut Laue-Langevin, 71 Avenue des Martyrs, 38000 Grenoble, France

4 Sincrotrone Trieste S.C.p.A. di Interesse Nazionale, Strada Statale 14 km 163.5, 34149 Basovizza, Trieste, Italy octahedral sites $(\mathrm{CN}=6)$, principally occupied by $\mathrm{Al}$ and $\mathrm{Fe}^{3+}$ (Dollase 1971; Franz and Liebscher 2004; Armbruster et al. 2006). Epidote group minerals are monoclinic in symmetry, with a structure described in the space group $P 2_{1} / \mathrm{m}$; however, possible deviations from the expected symmetry were also reported in some epidotes, for example in response to cation ordering (Franz and Liebscher 2004). The main building-block units in the structure of epidotes are: single-silicate tetrahedra $\left(\mathrm{SiO}_{4}\right)$, double-silicate tetrahedra $\left(\mathrm{Si}_{2} \mathrm{O}_{7}\right)$, and continuous chains of edge-sharing $M \mathrm{O}_{6}$ and $M \mathrm{O}_{4}(\mathrm{OH})_{2}$ octahedra running along [010]. The octahedral chains are bridged by $\mathrm{SiO}_{4}$ and $\mathrm{Si}_{2} \mathrm{O}_{7}$ units, as shown in Fig. 1. The crystal chemistry of the epidote group is complex. Clinozoisite (with ideal crystal chemical formula $\left.{ }^{A 1, A 2} \mathrm{Ca}_{2}{ }^{M 1, M 2, M 3} \mathrm{Al}_{3}\left(\mathrm{SiO}_{4}\right)\left(\mathrm{Si}_{2} \mathrm{O}_{7}\right) \mathrm{O}(\mathrm{OH})\right)$ is considered as the reference structure of the group, with three independent octahedral $M$ sites ( $M 1, M 2$ and $M 3$ ) fully occupied by $\mathrm{Al}$ and the two independent $A$ sites ( $A 1$ and $A 2$ ) occupied by Ca. 


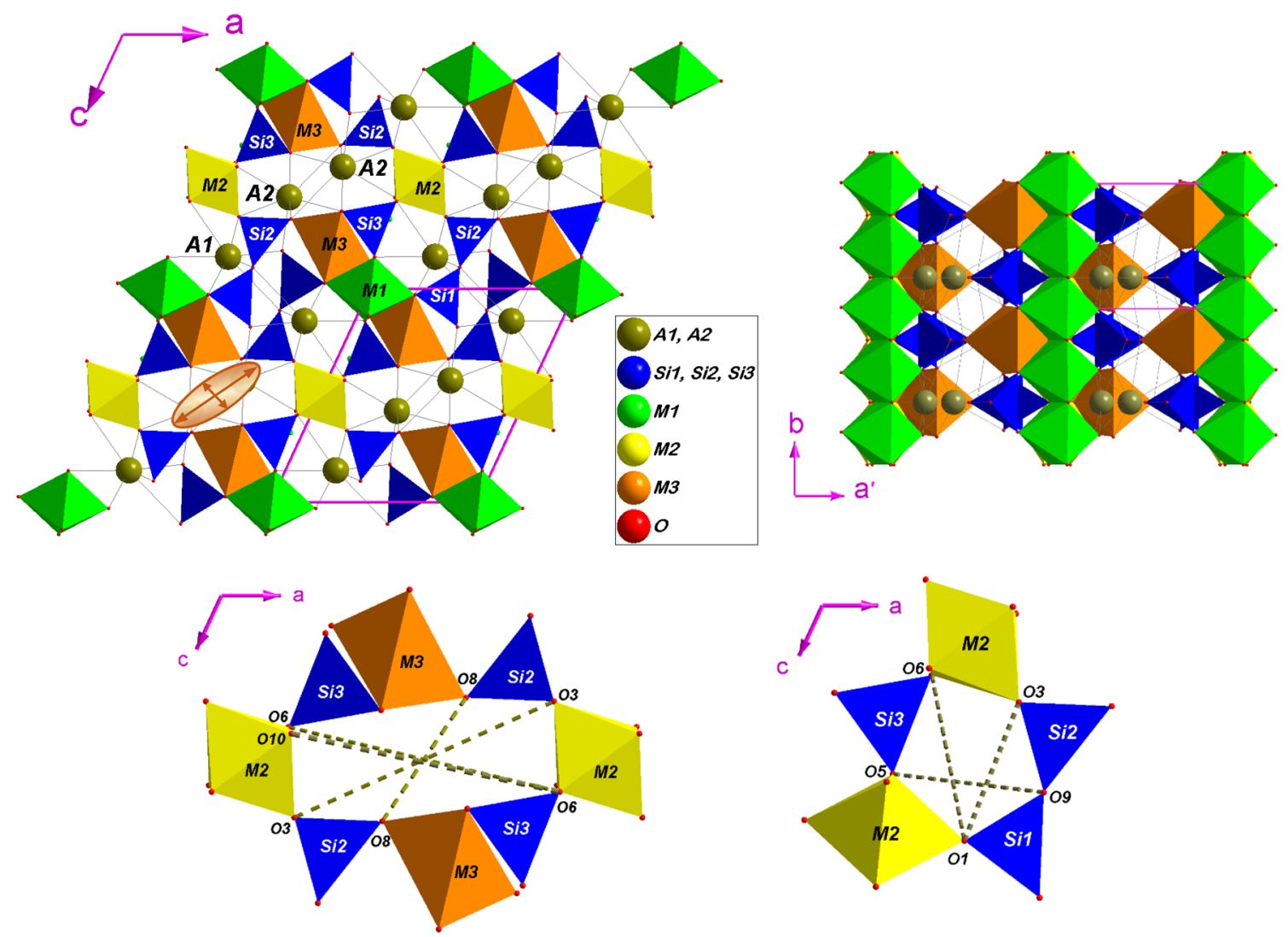

Fig. 1 Crystal structure of allanite viewed down [010] and [001], and overlying unit-strain ellipsoid based on Eulerian finite strain calculated between 293 and $673 \mathrm{~K}[\varepsilon 2 / / b, \varepsilon 1$ and $\varepsilon 3$ lying in the (010)plane, $\quad \varepsilon 1 \angle a^{\circ}=42.2(5)^{\circ} ; \quad \varepsilon 1=0.00517(3), \quad \varepsilon 2=0.00324(3)$, and $\left.\varepsilon 3=0.00201(4) \mathrm{K}^{-1}, \varepsilon 1: \varepsilon 2: \varepsilon 3=2.57: 1.61: 1\right]$. Tetrahedra (coordinated by $\mathrm{Si} 1, \mathrm{Si} 2$ and $\mathrm{Si} 3$ sites) and octahedra (coordinated by the $M 1, M 2$

Following the Commission of the International Mineralogical Association, three different subgroups can be considered (Armbruster et al. 2006). Among those, the allanite subgroup contains rare-earth elements (REE) bearing members, typified by the eponymous mineral "allanite". It is possible to derive the crystal chemistry of the allanite subgroup minerals from that of clinozoisite, on the basis of coupled homovalent and heterovalent substitutions, as follows:

$\left.{ }^{A 2}(\mathrm{REE})\right)^{3+}+{ }^{\mathrm{M} 3} \mathrm{M}^{2+} \rightarrow{ }^{A 2} \mathrm{Ca}^{2+}+{ }^{\mathrm{M} 3} \mathrm{M}^{3+}$

with a site population represented by: $A 1=\mathrm{M}^{2+}, A 2=\mathrm{M}^{3+}$, $M 1=\mathrm{M}^{3+}, M 2=\mathrm{M}^{3+}$, and $M 3=\mathrm{M}^{2+}$. In this light, the general crystal chemical formula of allanite is:

${ }^{A 1}(\mathrm{Ca})^{A 2}\left(\mathrm{REE}^{3+}\right)^{M 1, M 2}(\mathrm{Al})_{2}{ }^{M 3}\left(\mathrm{Fe}^{2+}\right)\left(\mathrm{SiO}_{4}\right)\left(\mathrm{Si}_{2} \mathrm{O}_{7}\right) \mathrm{O}(\mathrm{OH})$

(Dollase 1971; Bonazzi and Menchetti 1995; Gieré and Sorensen 2004; Armbruster et al. 2006; Bonazzi et al. 2009).

Epidotes occur in diverse geological environments. They mainly occur in low-grade metamorphic rocks (250-400 $\left.{ }^{\circ} \mathrm{C}, 0.1-0.2 \mathrm{GPa}\right)$. However, magmatic epidotes and $M 3$ sites) are shown as closed-faces polyhedra; large spheres represent the $A 1$ and $A 2$ sites. The 8-membered ring of polyhedra (with the diameters $O 3 \leftrightarrow 03, O 10 \leftrightarrow 06,06 \leftrightarrow 06$ and $O 8 \leftrightarrow 08)$ and the 5-membered ring (with the diameters $O 3 \leftrightarrow O 1, O 1 \leftrightarrow O 6$ and $O 9 \leftrightarrow O 5$ ) are also shown (see text for further details)

were also reported (Schmidt and Poli 2004). Their stability was observed over a wide range of $P-T$ conditions in geological systems with continental and oceanic crust composition (Poli and Schmidt 1998), influenced even by the Al/ $\mathrm{Fe}^{3+}$ ratio, $f \mathrm{O}_{2}$, fluids, etc. (e.g. Holdaway 1972; Liou 1973; Bird and Helgeson 1980; Bird et al. 1988; Klemd 2004). More specifically, allanite occurs as an important accessory mineral in granites and pegmatites (in which it plays an important role on trace element evolution, e.g. Gromet and Silver 1983; Sawka et al. 1984), in high-pressure gneisses (Carswell et al. 2000), in high-pressure garnet-amphibolites (Sorensen 1991), and in eclogites (Tribuzio et al. 1996). On the basis of a multi-methodological study (by experimental petrology, metamorphic petrology and trace element geochemistry), Hermann (2002) described the effect of LREE on the $P / T$ stability field of allanite, along with the experimentally determined element partitioning between allanite and a hydrous granitic melt at $1173 \mathrm{~K}$ and $2.0 \mathrm{GPa}$. Janots et al. (2007) investigated the thermochemistry of a synthetic dissakisite-(La) (i.e. the $\mathrm{Mg}$-counterpart of allanite: 
CaLaMgAl $\left.2\left(\mathrm{Si}_{2} \mathrm{O}_{7}\right)\left(\mathrm{SiO}_{4}\right) \mathrm{O}(\mathrm{OH})\right)$, showing how the stability window for dissakisite-clinozoisite lies between 520 and $820 \mathrm{~K}$ and $0.1-1.6 \mathrm{GPa}$, with a significant $P / T$ extension depending on the bulk-rock Ca-content. More recently, Corti et al. (2020) reported how the strain partitioning in host rock can control the LREE release from allanite-(Ce) in subduction zones.

In situ high-pressure $(\mathrm{H} P)$ and high-temperature $(\mathrm{H} T)$ experiments have mainly been devoted to clinozoisite/zoisite and epidote sensu stricto, to derive thermal and compressional elastic parameters or deformation mechanisms at the atomic scale (e.g. Catti et al. 1988; Holland et al. 1996; Pawley et al. 1996; Comodi and Zanazzi 1997; Franz and Liebscher 2004; Liebscher 2004; Gatta et al. 2010, 2011, 2012; Cámara et al. 2012; Qin et al. 2016; Li et al. 2021). Recently, the compressional behaviour and the main $P$-mediated deformation mechanisms at the atomic scale of a natural allanite were reported by Gatta et al. (2019), on the basis of an in situ synchrotron single-crystal X-ray diffraction experiment with a diamond anvil cell, providing also a comparative analysis between the $P$-behaviour of allanite and those of epidote sensu stricto and clinozoisite. This study is the extension of that by Gatta et al. (2019), and we aim at investigate the thermal behaviour and the $T$-induced structure rearrangement (at the atomic scale) of allanite-(Ce) by in situ synchrotron powder diffraction and single-crystal neutron diffraction. A comparative discussion of the experimental findings on allanite of this study and those previously reported for clinozoisite and epidote sensu stricto will be provided.

\section{Materials and experimental methods}

Crystals of allanite from the Alpe Veglia, Divedro valley, Central Alps (Monte Leone nappe), were used in this study. At the Monte Leone nappe, allanite crystals are hosted within pegmatites, involved in the Alpine greenschist metamorphism overprint. The greenschist overprint affected allanite breakdown into monazite and other REE-bearing minerals replacements in retrogressed pegmatites, owing to deformation (up to boudin-like textures) and fluid-assisted reaction. Pegmatite dikes hosting allanite show a strong "NYF" geochemical signature, represented by the occurrence of a unique mineralogy that includes: agardite-(Y), $\mathrm{Nb}$-anatase, cervandonite- $(\mathrm{Ce})$, chernovite-(Y), crichtonite-senaite group minerals, fergusonite-(Y), fluorite, gadolinite-(Y), monazite-(Ce), paraniite-(Y), niobian-rutile, synchysite-(Ce), and xenotime-(Y) (Dal Piaz 1975; Guastoni et al. 2006).

Chemical microanalyses were performed in wavelengthdispersive mode (EPMA-WDS) on a few optically homogeneous millimetric crystals of allanite, using a JEOL JXA8200 microprobe, at the Earth Sciences Department of the
University of Milano (ESD-UniMI). The microprobe was operated as follows: accelerating voltage of $15 \mathrm{kV}$, beam current of $5 \mathrm{nA}$, beam diameter of $5 \mu \mathrm{m}$, and counting time of $30 \mathrm{~s}$ on the peaks and $10 \mathrm{~s}$ on the backgrounds. Correction for matrix effects was applied using the PhiRhoZ method, as implemented in the JEOL suite of programs. The following natural and synthetic standards (with spectral lines) were used: grossular $(\mathrm{Ca} K \alpha, \mathrm{Si} K \alpha, \mathrm{Al} K \alpha)$, ilmenite (TiK$\alpha)$, fayalite $(\mathrm{Fe} K \alpha)$, forsterite $(\mathrm{Mg} K \alpha)$, rodonite $(\mathrm{Mn} K \alpha)$, metal Co $(\mathrm{Co} K \alpha)$, niccolite (As $K \alpha)$, synthetic $\mathrm{YPO}_{4}(\mathrm{Y} L \alpha, \mathrm{P} K \alpha)$, synthetic $\mathrm{ScPO}_{4}(\mathrm{Sc} L \alpha)$, synthetic $\mathrm{REEPO}_{4}$ set $(\mathrm{La} L \alpha, \mathrm{Ce} L \alpha$, $\operatorname{Pr} L \alpha, \operatorname{Nd} L \alpha, \operatorname{Sm} L \alpha, \operatorname{Eu} L \alpha, \operatorname{Gd} L \alpha, \operatorname{Tb} L \alpha, \operatorname{Dy} L \alpha, \operatorname{Ho} L \alpha, \operatorname{Er} L \alpha$, $\operatorname{Tm} L \alpha, \mathrm{Yb} L \alpha, L u L \alpha)$, synthetic $\mathrm{UO}_{2}(\mathrm{U} M \beta)$, synthetic $\mathrm{ThO}_{2}$ $(\mathrm{Th} M \alpha)$, and galena $(\mathrm{Pb} M \alpha)$. The selected crystals of allanite were found to be chemically homogeneous. The average unit-formula, based on (more than) 30 point-analyses and calculated following the protocol recommended by IMA Commission (Armbruster et al. 2006), is (Table 1):

$$
\begin{aligned}
& { }^{A 1}\left(\mathrm{Ca}_{0.87} \mathrm{Mn}_{0.06} \mathrm{Fe}_{0.06}^{3+} \mathrm{Fe}_{0.01}^{2+}\right)_{\Sigma 1.00}{ }^{A 2}\left(\mathrm{Ca}_{0.19} \mathrm{REE}_{0.72}\right)_{\Sigma 0.91} \\
& { }^{M 1}\left(\mathrm{Al}_{0.77} \mathrm{Fe}_{0.21}^{3+} \mathrm{Ti}_{0.02}\right)_{\Sigma 1.00}{ }^{M 2}\left(\mathrm{Al}_{1.00}\right)^{M 3}\left(\mathrm{Fe}_{0.91}^{2+} \mathrm{Mg}_{0.09}\right)_{\Sigma 1.00}{ }^{S i 1, S i 2, S i 3}\left(\mathrm{Si}_{3.08}\right) \mathrm{O}_{11}(\mathrm{OH}, \mathrm{O})
\end{aligned}
$$

with REE content: $\left(\mathrm{Y}_{0.01} \mathrm{La}_{0.16} \mathrm{Ce}_{0.28} \mathrm{Pr}_{0.03} \mathrm{Nd}_{0.15} \mathrm{Sm}_{0.03}\right.$ $\left.\mathrm{Gd}_{0.02} \mathrm{Ho}_{0.01} \mathrm{Th}_{0.02}\right)_{\Sigma 0.72}$. Allanite from the Alpe Veglia, Monte Leone nappe, is, therefore, rich of $\mathrm{La}, \mathrm{Ce}$ (dominant) and $\mathrm{Nd}$, among REE.

In situ high- $T$ X-ray diffraction experiments have been performed at the MCX beamline of the ELETTRA synchrotron (Trieste, Italy); the beamline setup description is in Rebuffi et al. (2014). A standard sample of powdered Si (Nist640C) was used for calibration. Crystals of allanite have been previously grinded in an agate mortar and the powders have been loaded in a quartz capillary $(300 \mu \mathrm{m}$ in diameter), which was kept spinning during the data collections. Two ramps have been performed, the first with a monochromatic primary beam $17.504 \mathrm{keV}$ in energy $(\lambda=0.7083 \AA)$, the second with a primary beam with $E=17.514 \mathrm{keV}(\lambda=0.7079 \AA)$. The X-ray diffraction patterns have been collected using the high-resolution scintillator detector mounted on the four-circle diffractometer. The same data collection strategy was adopted for both the $T$-ramps: $2 \theta$ range between $3.00^{\circ}$ and $17.00^{\circ}$, step-width $0.01^{\circ}$, exposure time $1 \mathrm{~s}$ per step. High-temperature conditions were obtained by means of the hot-air gas blower available at the beamline.

The unit-cell parameters of allanite at the different temperatures have been refined adopting a full-profile Rietveld refinement with the structure model of Gatta et al. (2019), using the GSAS-EXPGUI software (Larson and Von Dreele 2004; Toby 2001). During the last cycles, the following parameters have been simultaneously refined: scale factor, 
Table 1 Average composition of the allanite-(Ce) crystals, based on (more than) 30 WDS-EPMA point-analyses (b.d.l.=below detection limit)

\begin{tabular}{|c|c|c|c|c|}
\hline & wt $\%$ & e.s.d & & a.p.f.u \\
\hline $\mathrm{SiO}_{2}$ & 32.71 & 0.2 & $\mathrm{Si}$ & 3.08 \\
\hline $\mathrm{As}_{2} \mathrm{O}_{5}$ & 0.02 & 0.0 & As & $<0.001$ \\
\hline $\mathrm{PbO}$ & 0.04 & 0.0 & $\mathrm{~Pb}$ & $<0.001$ \\
\hline $\mathrm{Pr}_{2} \mathrm{O}_{3}$ & 0.77 & 0.1 & $\operatorname{Pr}$ & 0.03 \\
\hline $\mathrm{Eu}_{2} \mathrm{O}_{3}$ & 0.02 & 0.0 & $\mathrm{Eu}$ & $<0.001$ \\
\hline $\mathrm{Y}_{2} \mathrm{O}_{3}$ & 0.23 & 0.1 & $\mathrm{Y}$ & 0.01 \\
\hline $\mathrm{ThO}_{2}$ & 1.14 & 0.3 & Th & 0.02 \\
\hline $\mathrm{Nd}_{2} \mathrm{O}_{3}$ & 4.60 & 0.3 & $\mathrm{Nd}$ & 0.15 \\
\hline $\mathrm{Tb}_{2} \mathrm{O}_{3}$ & b.d.l & 0.0 & $\mathrm{~Tb}$ & - \\
\hline $\mathrm{P}_{2} \mathrm{O}_{5}$ & 0.08 & 0.0 & $\mathrm{P}$ & $<0.001$ \\
\hline $\mathrm{UO}_{2}$ & 0.08 & 0.1 & $\mathrm{U}$ & $<0.002$ \\
\hline $\mathrm{Sm}_{2} \mathrm{O}_{3}$ & 0.79 & 0.1 & $\mathrm{Sm}$ & 0.03 \\
\hline $\mathrm{Ho}_{2} \mathrm{O}_{3}$ & 0.17 & 0.1 & Но & 0.01 \\
\hline $\mathrm{CaO}$ & 10.60 & 0.4 & $\mathrm{Ca}$ & 1.06 \\
\hline $\mathrm{Gd}_{2} \mathrm{O}_{3}$ & 0.52 & 0.1 & $\mathrm{Gd}$ & 0.02 \\
\hline $\mathrm{Er}_{2} \mathrm{O}_{3}$ & b.d.l & 0.0 & $\mathrm{Er}$ & - \\
\hline $\mathrm{La}_{2} \mathrm{O}_{3}$ & 4.66 & 0.3 & $\mathrm{La}$ & 0.16 \\
\hline $\mathrm{Dy}_{2} \mathrm{O}_{3}$ & b.d.l & 0.0 & Dy & - \\
\hline $\mathrm{Tm}_{2} \mathrm{O}_{4}$ & 0.05 & 0.1 & $\mathrm{Tm}$ & $<0.001$ \\
\hline $\mathrm{Ce}_{2} \mathrm{O}_{3}$ & 8.23 & 0.3 & $\mathrm{Ce}$ & 0.28 \\
\hline $\mathrm{Yb}_{2} \mathrm{O}_{3}$ & 0.09 & 0.1 & $\mathrm{Yb}$ & $<0.003$ \\
\hline $\mathrm{Lu}_{2} \mathrm{O}_{3}$ & 0.14 & 0.1 & $\mathrm{Lu}$ & $<0.004$ \\
\hline $\mathrm{V}_{2} \mathrm{O}_{3}$ & b.d.l & 0.0 & $\mathrm{~V}$ & - \\
\hline $\mathrm{MgO}$ & 0.62 & 0.1 & $\mathrm{Mg}$ & 0.09 \\
\hline $\mathrm{Al}_{2} \mathrm{O}_{3}$ & 15.99 & 0.3 & $\mathrm{Al}$ & 1.77 \\
\hline $\mathrm{MnO}$ & 0.80 & 0.1 & $\mathrm{Mn}$ & 0.06 \\
\hline $\mathrm{Sc}_{2} \mathrm{O}_{3}$ & 0.03 & 0.0 & $\mathrm{Sc}$ & $<0.002$ \\
\hline $\mathrm{TiO}_{2}$ & 0.22 & 0.1 & $\mathrm{Ti}$ & 0.02 \\
\hline $\mathrm{CoO}$ & 0.02 & 0.0 & Co & $<0.001$ \\
\hline $\mathrm{FeO}$ & 11.70 & 0.4 & $\mathrm{Fe}^{2+}$ & 0.92 \\
\hline $\mathrm{Fe}_{2} \mathrm{O}_{3}$ & 3.81 & 0.4 & $\mathrm{Fe}^{3+}$ & 0.27 \\
\hline $\mathrm{H}_{2} \mathrm{O}$ & 1.59 & & $\mathrm{H}$ & 1.0 \\
\hline Tot & 99.73 & & & \\
\hline
\end{tabular}

Crystal formula calculated following the protocol recommended by the IMA Commission (Armbruster et al. 2006), based on 8 cations per formula unit

${ }^{A 1}\left(\mathrm{Ca}_{0.87} \mathrm{Mn}_{0.06} \mathrm{Fe}^{3+}{ }_{0.06} \mathrm{Fe}^{2+}{ }_{0.01}\right)_{\Sigma 1.00}{ }^{A 2}\left(\mathrm{Ca}_{0.19} \mathrm{REE}_{0.72}\right)_{\Sigma 0.91}{ }^{M 1}\left(\mathrm{Al}_{0.77}\right.$ $\left.\mathrm{Fe}^{3+}{ }_{0.21} \mathrm{Ti}_{0.02}\right)_{\Sigma 1.00}$

${ }^{M 2}\left(\mathrm{Al}_{1.00}\right)^{M 3}\left(\mathrm{Fe}^{2+}{ }_{0.91} \mathrm{Mg}_{0.09}\right)_{\Sigma 1.00}{ }^{\text {Si1,Si2,Si3 }}\left(\mathrm{Si}_{3.08}\right) \mathrm{O}_{11}(\mathrm{OH}, \mathrm{O})$,

with $\mathrm{REE}+\mathrm{Th}$ a.p.f.u.: $\quad\left(\mathrm{Y}_{0.01} \mathrm{La}_{0.16} \mathrm{Ce}_{0.28} \mathrm{Pr}_{0.03} \mathrm{Nd}_{0.15} \mathrm{Sm}_{0.03} \mathrm{Gd}_{0.02}\right.$ $\left.\mathrm{Ho}_{0.01} \mathrm{Th}_{0.02}\right)_{\Sigma 0.72}$

background (Chebyshev polynomial, 13 parameters), peak profile (pseudo-Voigt function of Thompson et al. 1988) and unit-cell parameters.

Single-crystal neutron diffraction (SC-ND) data were first collected at room temperature from a crystal of allanite (approx. $4 \times 3 \times 2 \mathrm{~mm}^{3}$ ) on the four-circle diffractometer D19
Table 2 Details pertaining to the neutron data collections and structure refinements of allanite at different temperatures ( $T$-uncertainty: $\pm 1 \mathrm{~K}$ )

\begin{tabular}{|c|c|c|c|}
\hline & $293 \mathrm{~K}$ & $848 \mathrm{~K}$ & $1023 \mathrm{~K}$ \\
\hline Beamline & D19, ILL & D9, ILL & D9, ILL \\
\hline$a(\AA)$ & $8.9012(1)$ & $8.958(2)$ & $8.975(4)$ \\
\hline$b(\AA)$ & $5.7261(2)$ & $5.7573(14)$ & $5.763(2)$ \\
\hline$c(\AA)$ & $10.1182(2)$ & $10.193(3)$ & $10.232(4)$ \\
\hline$\beta(\AA)$ & $114.838(2)$ & $115.16(1)$ & $115.28(2)$ \\
\hline$V\left(\AA^{3}\right)$ & $468.01(2)$ & $475.8(2)$ & $478.6(3)$ \\
\hline Space group & $P 2_{1} / m$ & $P 2_{1} / m$ & $P 2_{1} / m$ \\
\hline$\lambda(\AA)$ & 0.9500 & 0.8360 & 0.8360 \\
\hline$\theta_{\max }\left({ }^{\circ}\right)$ & 61.3 & 49.2 & 48.9 \\
\hline No. measured reflections & 9402 & 2910 & 3152 \\
\hline No. unique reflections & 3156 & 2876 & 3073 \\
\hline No. uniq. refl. with $F_{\mathrm{o}}>4 \sigma\left(F_{o}\right)$ & 3096 & 2457 & 1694 \\
\hline No. refined parameters & 129 & 129 & 130 \\
\hline$R_{\text {int }}$ & 0.07 & $0.01 *$ & $0.01 *$ \\
\hline$R_{\sigma}$ & 0.04 & 0.04 & 0.05 \\
\hline$R_{1}(F)$ with $F_{\mathrm{o}}>4 \sigma\left(F_{\mathrm{o}}\right)$ & 0.043 & 0.037 & 0.083 \\
\hline $\mathrm{w} R_{2}\left(F^{2}\right)$ & 0.081 & 0.071 & 0.162 \\
\hline GooF & 1.417 & 1.373 & 1.641 \\
\hline Residuals $\left(\mathrm{fm} / \AA^{3}\right)$ & $-1.7 /+1.4$ & $-0.9+/ 0.8$ & $-1.4 /+1.1$ \\
\hline
\end{tabular}

Statistical parameters according to the SHELXL definition (Sheldrick 2008, 2015)

*Check based on 35 equivalent refls at $848 \mathrm{~K}$ and 72 refls at $1023 \mathrm{~K}$

installed at the Institute Laue-Langevin (ILL), Grenoble. The crystal was glued on a vanadium pin with diameter size of $1 \mathrm{~mm}$. Diffraction data were collected with a wavelength of $0.9500 \AA$, obtained from a $331 \mathrm{Cu}$ monochromator at $2 \theta_{\mathrm{M}}=69.91^{\circ}$ take-off angle, and a large two-dimensional area detector was used. The measurement strategy consisted on 5 several $\omega$ scans with steps of $0.07^{\circ}$ at different $\chi$ and $\varphi$ positions. The Multi-Detector Acquisition Data Software $(M A D)$ from ILL was used for data collection. Unit-cell determination was done using PFIND and DIRAX programs, and processing of the raw data was applied using RETREAT and RAFD19 programs (McIntyre and Stansfield 1988; Wilkinson et al. 1988; Duisenberg 1992). A total number of 9402 reflections were collected (with $-14 \leq h \leq+14$, $-10 \leq k \leq+10$ and $-18 \leq l \leq+16)$, out of which 3156 were unique $\left(R_{\sigma}=0.0409, R_{\text {int }}=0.0705\right.$, Laue class $\left.2 / m\right)$ and 3096 with $I_{\mathrm{o}}>2 \sigma\left(I_{\mathrm{o}}\right)$, with $d_{\text {min }}=0.54 \AA$ (Table 2). The lattice was found to be metrically monoclinic, and the reflection conditions were found to be consistent with the space group $P 2_{1} / m$. Absorption correction was applied, based on composition and shape of the crystal, using the ILL D19ABS program (Matthewman et al. 1982).

Two additional in situ HT SC-ND data collections were performed at 848 and $1023 \mathrm{~K}$, on the four-circle 
diffractometer D9 at ILL. High temperature was generated using a self-dedicate close shell four-circle vanadium-furnace (uncertainty: $\pm 1 \mathrm{~K}$ ). Diffraction data were collected with a wavelength of $0.8360 \AA$. The measurement strategy consisted of a series of $\omega$-scans or $\omega-2 \theta$ scans for low and high- $Q$ reflections, respectively. The Bragg reflections were collected varying the $\omega$-range as a function of the instrument resolution curve. Intensity integration, background and Lorentz factor correction of the scans were done with the Racer program (written by C. Wilkinson and G. McIntyre, ILL integration program suite, https://forge.ill.fr/projects/ sxtalsoft/repository/show/racer). Absorption correction was applied, based on composition and shape of the crystal using the ILL program Datap (the current version of this program is available online on https://forge.ill.fr/). At both the temperatures, the lattice was found to be metrically monoclinic, with reflection conditions consistent with the space group $P 2_{1} / m$. The Wilson plot and the statistics of distributions of the normalised structure factors suggest that the structure of allanite is centrosymmetric at 293,848 and $1023 \mathrm{~K}$. Further details pertaining to the data collected at 848 and 1023 are listed in Table 2.

The anisotropic structure refinements, based on the intensity data collected at room and high temperature, were conducted using the software SHELXL (release 2018-3; Sheldrick 1997, 2008, 2015), starting from the structure model of Gatta et al. (2019), in the space group $P 2_{1} / m$. To correct the secondary isotropic extinction effect, the formalism of Larson (1967) was used, as implemented in SHELXL. Neutron scattering lengths of $\mathrm{Ca}, \mathrm{Mn}, \mathrm{Ce}, \mathrm{La}$, $\mathrm{Fe}, \mathrm{Al}, \mathrm{Si}, \mathrm{O}$ and $\mathrm{H}$ were taken from Sears (1986). Considering the average chemical composition of the allanite of this study, the atomic sites were modelled as follows: the $A 1$ and $A 2$ sites were modelled, respectively, with mixed $(\mathrm{Ca}+\mathrm{Mn})$ and $(\mathrm{Ca}+\mathrm{La})$ neutron scattering lengths, and the fraction of Ca vs. Mn (A1) and Ca vs. La (A2) were refined; the $M 1$ and $M 3$ octahedral sites as populated by $(\mathrm{Fe}+\mathrm{Al})$, and the fraction $\mathrm{Fe}$ vs. $\mathrm{Al}$ was refined, and the $M 2$ site as populated by $\mathrm{Al}$ only; the three independent tetrahedral sites (i.e. Si1, Si2 and Si3) were modelled as fully occupied by $\mathrm{Si}$. Test refinements were conducted using a mixed $(\mathrm{Ca}+\mathrm{Ce})$ neutron scattering length to model the $A 2$ site, but the figures of merit were worse than using the $(\mathrm{Ca}+\mathrm{La})$ model, likely for the similar scattering length of $\mathrm{Ca}$ and $\mathrm{Ce}$ (i.e. $b_{\mathrm{Ca}}=4.70 \mathrm{fm}, b_{\mathrm{Ce}}=4.84 \mathrm{fm}$, $b_{\mathrm{La}}=8.24 \mathrm{fm}$ ). For all the refinements, convergence was rapidly achieved and, at the end of the last cycles of refinement, no significant correlation was observed in the variance-covariance matrix of the refined parameters. Only for the refinement at $1023 \mathrm{~K}$, to overcome the effects of the high number of reflections with $I_{\mathrm{o}}<2 \sigma\left(I_{\mathrm{o}}\right)$ on the statistical parameters as calculated in SHELXL, an off-line merging for symmetry with a filter for $I_{\mathrm{o}}>2 \sigma\left(I_{\mathrm{o}}\right)$ was applied. The principal statistical parameters of the structure refinements are listed in Table 2. Atomic coordinates, site occupancies and displacement parameters are given in Tables 3, 4 and 5. Bond distances and other relevant structural parameters are reported in Table 6.

\section{Results: thermal behaviour of allanite}

The evolution of the lattice parameters of allanite with temperature (up to $1073 \mathrm{~K}$ ) is shown in Fig. 2 and Table 7. Up to $700 \mathrm{~K}$, the thermal behaviour along the three principal crystallographic axes, of the monoclinic $\beta$ angle and of the unitcell volume follow monotonically increasing trends, which are almost linear. At $T>700-800 \mathrm{~K}$, a drastic change takes place: an inversion of the trend is observed along the $a$ and $b$ axes (more pronounced along $b$ ) and for the monoclinic $\beta$ angle; in contrast, an anomalous increase of the expansion is observed along the $c$ axis, which somehow governs the positive trend experienced by the unit-cell volume at $T>700-800 \mathrm{~K}$. In addition, data collected back to room $T$, after the $\mathrm{H} T$ experiments up to $1073 \mathrm{~K}$, show unit-cell parameters significantly different with respect to those previously measured at $293 \mathrm{~K}$ (Fig. 2; Table 7). We can, therefore, assume that allanite responds with an ideal elastic behaviour up to $700 \mathrm{~K}$, and at $T>700-800 \mathrm{~K}$ its behaviour deviates from the elasticity field.

To describe the axial and volume thermal behaviour of allanite within the elasticity domain, a modified Holland and Powell (1998) Equation of State (mHP-EoS) was fitted to the experimental data up to $c a$. $700 \mathrm{~K}$, using the EoSFit7-GUI program (Angel et al. 2014; Gonzalez-Platas et al. 2016). The mHP-EoS parameters, refined using the data weighted by their uncertainties, are listed in Table 8 . For the unitcell volume, the fit converges to: $V_{\mathrm{T} 0}=467.33(6) \AA^{3}$ and $\alpha_{\mathrm{T} 0}(V)=2.8(3) \times 10^{-5} \mathrm{~K}^{-1}$ (being $\alpha_{0}(V)=2.7(8) \times 10^{-5} \mathrm{~K}^{-1}$ and $\alpha_{1}(V)=-2.8(9) \times 10^{-4} \mathrm{~K}^{-1 / 2}$ in mHP-EoS). The thermal anisotropy, derived on the basis of the axial expansion along the three main crystallographic directions, is the following: $\alpha_{\mathrm{T} 0}(a): \alpha_{\mathrm{T} 0}(b): \alpha_{\mathrm{T} 0}(c)=1.08: 1: 1.36$ (Table 8). The monoclinic $\beta$-angle value increases linearly with temperature, with: $\beta_{\mathrm{T}} / \beta_{0}=0.99991(1)+3.63(4) \times 10^{-6} T\left(R^{2}=0.9992\right)($ Fig. 2$)$.

Orientation and magnitude of the principal unit-strain components between 293 and $673 \mathrm{~K}$, derived on the basis of the finite Eulerian strain tensor, were calculated using the Win_Strain software (by RJ Angel, www.rossangel. com), with the Cartesian axial system: $x / / a^{*}$ and $y / / b$. The strain ellipsoid is oriented with the mid axis $(\varepsilon 2)$ parallel to the $b$-axis, and the major $(\varepsilon 1)$ and minor $(\varepsilon 3)$ axes dispersed in the (010)-plane: $\varepsilon 1$ describes an angle of $42.2(5)^{\circ}$ from $a$ (and consequently $147.2(5)^{\circ}$ from $c$ ) (Fig. 1). The elastic anisotropy of allanite, deduced from the unit-strain coefficients between 293 and $673 \mathrm{~K}$, is more pronounced 
Table 3 Fractional atomic coordinates, site occupancy factors (s.o.f) and equivalent displacement parameters (Ueq, in $\left.\AA^{2}\right)$ pertaining to the neutron structure refinements of allanite at different temperatures

\begin{tabular}{|c|c|c|c|c|c|}
\hline$T 293 \mathrm{~K}$ & $x / a$ & $y / b$ & $z / c$ & Ueq & s.o.f. \\
\hline$A 1$ & $0.75869(12)$ & 0.75 & $0.15125(9)$ & $0.01067(18)$ & Ca 0.946 (3), Mn 0.054 (3) \\
\hline$A 2$ & $0.59549(8)$ & 0.75 & $0.42858(6)$ & $0.00994(13)$ & Ca 0.637 (8), La 0.363 (8) \\
\hline Si1 & $0.33896(10)$ & 0.75 & $0.03924(8)$ & $0.00600(10)$ & Si 1.0 \\
\hline $\mathrm{Si} 2$ & $0.68598(9)$ & 0.25 & $0.27913(8)$ & $0.00578(10)$ & Si 1.0 \\
\hline Si3 & $0.18694(9)$ & 0.75 & $0.32286(8)$ & $0.00540(9)$ & Si 1.0 \\
\hline$M 1$ & 0 & 0 & 0 & $0.00639(13)$ & $\mathrm{Al} 0.740$ (4), Fe 0.260 (4) \\
\hline$M 2$ & 0 & 0 & 0.5 & $0.00505(11)$ & Al 1.0 \\
\hline M3 & $0.29956(5)$ & 0.25 & $0.21493(4)$ & $0.00824(8)$ & $\mathrm{Al} 0.102$ (5), Fe 0.898 (5) \\
\hline$O 1$ & $0.23391(6)$ & $-0.01061(7)$ & $0.02922(5)$ & $0.01056(6)$ & O 1.0 \\
\hline$O 2$ & $0.31150(6)$ & $-0.02708(8)$ & $0.36464(5)$ & $0.01024(6)$ & O 1.0 \\
\hline$O 3$ & $0.79578(6)$ & $0.01412(7)$ & $0.33884(5)$ & $0.00987(6)$ & O 1.0 \\
\hline$O 4$ & $0.05527(8)$ & 0.25 & $0.13041(6)$ & $0.00821(8)$ & O 1.0 \\
\hline 05 & $0.04850(8)$ & 0.75 & $0.15083(6)$ & $0.00855(8)$ & O 1.0 \\
\hline 06 & $0.06729(7)$ & 0.75 & $0.41019(6)$ & $0.00755(8)$ & O 1.0 \\
\hline 07 & $0.51035(8)$ & 0.75 & $0.17944(7)$ & $0.01111(9)$ & O 1.0 \\
\hline 08 & $0.53847(9)$ & 0.25 & $0.32939(8)$ & $0.01593(11)$ & O 1.0 \\
\hline 09 & $0.61354(10)$ & 0.25 & $0.10150(7)$ & $0.01513(11)$ & O 1.0 \\
\hline$O 10$ & $0.08430(7)$ & 0.25 & $0.42758(6)$ & $0.00752(8)$ & O 1.0 \\
\hline$H$ & $0.0597(2)$ & 0.25 & $0.32305(15)$ & $0.0209(2)$ & H 1.0 \\
\hline$T 848 \mathrm{~K}$ & $x / a$ & $y / b$ & $z / c$ & Ueq & s.o.f. \\
\hline$A 1$ & $0.75877(18)$ & 0.75 & $0.15129(13)$ & $0.0239(3)$ & Ca 0.948 (4), Mn 0.052 (4) \\
\hline$A 2$ & $0.59494(10)$ & 0.75 & $0.42642(8)$ & $0.02102(19)$ & Ca 0.601 (9), La 0.399 (9) \\
\hline Si 1 & $0.33798(11)$ & 0.75 & $0.03825(10)$ & $0.01200(13)$ & Si 1.0 \\
\hline$S i 2$ & $0.68589(11)$ & 0.25 & $0.27834(10)$ & $0.01166(12)$ & Si 1.0 \\
\hline Si3 & $0.18720(11)$ & 0.75 & $0.32366(9)$ & $0.01101(12)$ & Si 1.0 \\
\hline$M 1$ & 0 & 0 & 0 & $0.01448(17)$ & $\mathrm{Al} 0.727$ (4), Fe 0.273 (4) \\
\hline$M 2$ & 0 & 0 & 0.5 & $0.01175(14)$ & Al 1.0 \\
\hline M3 & $0.29957(6)$ & 0.25 & $0.21574(6)$ & $0.01926(12)$ & Al 0.099 (5), Fe 0.901 (5) \\
\hline$O 1$ & $0.23387(7)$ & $-0.01150(10)$ & $0.02856(7)$ & $0.02042(9)$ & O 1.0 \\
\hline$O 2$ & $0.31127(7)$ & $-0.02763(11)$ & $0.36559(6)$ & $0.01990(9)$ & O 1.0 \\
\hline$O 3$ & $0.79514(7)$ & $0.01490(10)$ & $0.33913(6)$ & $0.01963(9)$ & O 1.0 \\
\hline$O 4$ & $0.05689(9)$ & 0.25 & $0.12915(8)$ & $0.01585(11)$ & O 1.0 \\
\hline 05 & $0.04981(10)$ & 0.75 & $0.15192(8)$ & $0.01680(12)$ & O 1.0 \\
\hline 06 & $0.06687(9)$ & 0.75 & $0.40941(8)$ & $0.01536(10)$ & O 1.0 \\
\hline 07 & $0.50932(11)$ & 0.75 & $0.17772(9)$ & $0.02283(15)$ & O 1.0 \\
\hline 08 & $0.53781(11)$ & 0.25 & $0.32636(11)$ & $0.0298(2)$ & O 1.0 \\
\hline$O 9$ & $0.61552(14)$ & 0.25 & $0.10186(9)$ & $0.0297(2)$ & O 1.0 \\
\hline$O 10$ & $0.08361(9)$ & 0.25 & $0.42835(8)$ & $0.01569(11)$ & O 1.0 \\
\hline$H$ & $0.0594(3)$ & 0.25 & $0.3258(2)$ & $0.0363(4)$ & H 1.0/0.96 (1) \\
\hline$T 1023 \mathrm{~K}$ & $x / a$ & $y / b$ & $z / c$ & Ueq & s.o.f. \\
\hline$A 1$ & $0.7592(6)$ & 0.75 & $0.1515(5)$ & $0.0381(11)$ & Ca 0.957 (10), Mn 0.043 (10) \\
\hline$A 2$ & $0.5965(4)$ & 0.75 & $0.4254(3)$ & $0.0357(8)$ & $\mathrm{Ca} 0.61(2), \mathrm{La} 0.39$ (2) \\
\hline Si1 & $0.3387(4)$ & 0.75 & $0.0383(4)$ & $0.0254(6)$ & Si 1.0 \\
\hline $\mathrm{Si} 2$ & $0.6862(4)$ & 0.25 & $0.2781(4)$ & $0.0241(6)$ & Si 1.0 \\
\hline Si3 & $0.1873(4)$ & 0.75 & $0.3237(4)$ & $0.0240(6)$ & Si 1.0 \\
\hline$M 1$ & 0 & 0 & 0 & $0.0284(7)$ & $\mathrm{Al} 0.697$ (12), Fe 0.303 (12) \\
\hline$M 2$ & 0 & 0 & 0.5 & $0.0258(7)$ & Al 1.0 \\
\hline
\end{tabular}


Table 3 (continued)

\begin{tabular}{|c|c|c|c|c|c|}
\hline$T 1023 \mathrm{~K}$ & $x / a$ & $y / b$ & $z / c$ & Ueq & s.o.f. \\
\hline$M 3$ & $0.2994(2)$ & 0.25 & $0.2162(2)$ & $0.0337(6)$ & Al 0.169 (14), Fe 0.831 (14) \\
\hline$O 1$ & $0.2349(2)$ & $-0.0114(4)$ & $0.0291(3)$ & $0.0351(4)$ & O 1.0 \\
\hline$O 2$ & $0.3114(2)$ & $-0.0266(4)$ & $0.3654(2)$ & $0.0344(4)$ & O 1.0 \\
\hline$O 3$ & $0.7949(2)$ & $0.0151(4)$ & $0.3387(2)$ & $0.0340(4)$ & O 1.0 \\
\hline$O 4$ & $0.0571(3)$ & 0.25 & $0.1285(3)$ & $0.0291(5)$ & O 1.0 \\
\hline 05 & $0.0499(4)$ & 0.75 & $0.1522(3)$ & $0.0310(5)$ & O 1.0 \\
\hline 06 & $0.0682(3)$ & 0.75 & $0.4092(3)$ & $0.0293(5)$ & O 1.0 \\
\hline 07 & $0.5088(4)$ & 0.75 & $0.1766(4)$ & $0.0382(7)$ & O 1.0 \\
\hline 08 & $0.5370(4)$ & 0.25 & $0.3232(4)$ & $0.0460(8)$ & O 1.0 \\
\hline$O 9$ & $0.6172(5)$ & 0.25 & $0.1013(4)$ & $0.0463(8)$ & O 1.0 \\
\hline$O 10$ & $0.0839(4)$ & 0.25 & $0.4294(3)$ & $0.0303(5)$ & O 1.0 \\
\hline$H$ & $0.0609(10)$ & 0.25 & $0.3297(8)$ & $0.050(2)$ & Н 0.89 (3) \\
\hline
\end{tabular}

if compared to that obtained considering the principal crystallographic directions, being: $\varepsilon 1=0.00517(3) \mathrm{K}^{-1}$, $\varepsilon 2=0.00324(3) \mathrm{K}^{-1}$, and $\varepsilon 3=0.00201(4) \mathrm{K}^{-1}$, with the resulting anisotropic scheme: $\varepsilon 1: \varepsilon 2: \varepsilon 3=2.57: 1.61: 1$.

\section{Results: effect of temperature at the atomic scale}

The effects of temperature on the crystal structure of allanite-(Ce) are here described starting from the evolution of bond distances and geometry of the coordination polyhedra, based on the single-crystal neutron refinements, as follows:

- Between 293 and 1023 K, the Si-tetrahedra show only a slight expansion, as deduced from an average increase of bond distances (corrected by "rigid body motion", Downs et al. 1992; Downs 2000) between 0.01 and $0.02 \AA$. The polyhedra do not experience any remarkable increase of the distortion. Even the Sil tetrahedron, which is the most distorted one at room $T$, shows a difference between the longest and the shortest bond length $\left(\Delta l_{\max }\right)$ that increases only from $\sim 0.06$ to $\sim 0.07 \AA$.

- Even the $M 1, M 2$ and $M 3$ octahedra show only a modest expansion between 293 and $1023 \mathrm{~K}$, with an increase of bond distances ranging between 0.01 and $0.04 \AA$. The $T$-induced distortion is modest: the most distorted octahedron, $M 3$, shows a $\Delta l_{\max } \sim 0.33 \AA$ at $293 \mathrm{~K}$, which increases to $\sim 0.37 \AA$ at $1023 \mathrm{~K}$.

- The bond distances of the $A 1$ and $A 2$ polyhedra increase by $0.01-0.03 \AA$, between 293 and $1023 \mathrm{~K}$.

The inter-polyhedral changes with $T$ can be described on the basis of the deformation of the 5-membered rings of polyhedra (M2-Si3-M2-Si2-Si1, Fig. 1), confining the cavities in which the $A 1$ site lies, and of the 8-membered rings of polyhedra (M2-Si3-M3-Si2-M2-Si3-M3-Si2), in which the $A 2$ site lies (Fig. 1), acting mainly by polyhedral tilting. The 5-membered ring contains the Si1- and Si2-tetrahedra, bridged by O9: the Si1-O9-Si2 angle increases from $145.56(7)^{\circ}$ to $147.5(3)^{\circ}$ between 293 and $1023 \mathrm{~K}$. In the same temperature-range, the "diameters" of the ring increase their lengths, though differently: $O 3 \leftrightarrow O 1$ by $\sim 0.035 \AA$, $O 6 \leftrightarrow O 1$ by $\sim 0.022 \AA$ and $O 9 \leftrightarrow O 5$ by $\sim 0.012 \AA$ (Table 6). Even the diameters of the 8-membered rings of polyhedra change differently in response to the applied temperature: $O 6 \leftrightarrow O 10$ increases its length by $\sim 0.042 \AA, O 3 \leftrightarrow O 3$ by $\sim 0.074 \AA$, $06 \leftrightarrow 06$ by $\sim 0.030 \AA$, and $08 \leftrightarrow 08$ by $\sim 0.136 \AA$ (Table 6 ). The highest directional expansion, observed along the $O 8 \leftrightarrow O 8$ vector, generates the major effect along [001] and a subordinate effect along [010], and that along $O 3 \leftrightarrow O 3$ has similar effects on [100] and [001]. However, it is worth to note that some of the aforementioned diameters do not show a monotonic trend with $T$ : the lengths of $O 6 \leftrightarrow O 10$ (major component along [100], minors along [010] and [001]), O6 $\leftrightarrow 66$ (major component along [100], minors along [010] and [001]) and $O 9 \leftrightarrow O 5$ (major component along [100], minor along [010]) first increase between 293 and $848 \mathrm{~K}$, and then decrease between 848 and $1023 \mathrm{~K}$; a similar behaviour as that shown along the unit-cell edges $a$ and $b$ with $T$.

The neutron structure refinement based on the data collected at room $T$ shows a cationic population at the $A 1, A 2, M 1, M 2$ and $M 3$ sites that is compatible, at a first approximation, with the EPMA-WDS data. The refinement converges with: the $A 1$ site populated by $\sim 95 \% \mathrm{Ca}+\sim 5 \% \mathrm{Mn}$, the $A 2$ site populated by $\mathrm{Ca}$ and REE (here modelled with $\sim 64 \% \mathrm{Ca}+\sim 36 \% \mathrm{La}$ ), $M 1$ populated by $\sim 74 \% \mathrm{Al}+\sim 26 \% \mathrm{Fe}$ and $\mathrm{M} 3$ by $\sim 10 \% \mathrm{Al}+\sim 90 \% \mathrm{Fe}$, $M 2$ as fully occupied by Al. All the tetrahedral sites are fully occupied by Si. At high temperature, there is no evidence of ordering change at a significant level $(\geq 3 \sigma)$. Only at the 
Table 4 Atomic displacement parameters $\left(\AA^{2}\right)$ in allanite structure at different temperatures, in the expression: $-2 \pi^{2}\left[\left(h a^{*}\right)^{2} U_{11}+\cdots+2 h k a^{*} b^{*}\right.$ $\left.U_{12}+\cdots+2 k l b^{*} c^{*} U_{23}\right]$

\begin{tabular}{|c|c|c|c|c|c|c|}
\hline$T 293 \mathrm{~K}$ & $U_{11}$ & $U_{22}$ & $U_{33}$ & $U_{23}$ & $U_{13}$ & $U_{12}$ \\
\hline$A 1$ & $0.0164(3)$ & $0.0085(3)$ & $0.0106(3)$ & 0 & $0.0090(2)$ & 0 \\
\hline$A 2$ & $0.0086(2)$ & $0.0122(2)$ & 0.00795 (19) & 0 & $0.00247(15)$ & 0 \\
\hline$S i 1$ & $0.0062(2)$ & $0.0055(2)$ & $0.0062(2)$ & 0 & $0.00255(18)$ & 0 \\
\hline $\mathrm{Si} 2$ & $0.0050(2)$ & $0.0056(2)$ & $0.0068(2)$ & 0 & $0.00252(18)$ & 0 \\
\hline Si3 & $0.0048(2)$ & 0.0059 (2) & $0.0063(2)$ & 0 & $0.00316(17)$ & 0 \\
\hline$M 1$ & $0.0061(2)$ & 0.0049 (2) & $0.0079(2)$ & $-0.00029(15)$ & $0.00267(15)$ & $-0.00006(15)$ \\
\hline$M 2$ & $0.0042(3)$ & $0.0040(2)$ & $0.0071(2)$ & $-0.0003(2)$ & $0.0024(2)$ & $-0.0002(2)$ \\
\hline$M 3$ & $0.00664(13)$ & $0.00800(13)$ & $0.00821(13)$ & 0 & $0.00128(10)$ & 0 \\
\hline$O 1$ & 0.00915 (14) & $0.00704(12)$ & $0.01602(15)$ & $0.00158(11)$ & $0.00581(12)$ & $0.00171(11)$ \\
\hline$O 2$ & 0.00940 (14) & $0.01065(13)$ & $0.01172(13)$ & $-0.00219(11)$ & $0.00545(11)$ & $-0.00373(11)$ \\
\hline$O 3$ & 0.00744 (14) & $0.00630(12)$ & $0.01153(14)$ & $-0.00088(10)$ & $-0.00026(11)$ & 0.00099 (10) \\
\hline$O 4$ & 0.00708 (18) & $0.00855(17)$ & $0.00836(17)$ & 0 & $0.00263(14)$ & 0 \\
\hline 05 & 0.00787 (19) & $0.00981(18)$ & $0.00686(16)$ & 0 & $0.00200(14)$ & 0 \\
\hline O6 & $0.00906(18)$ & $0.00620(16)$ & $0.01024(17)$ & 0 & $0.00685(14)$ & 0 \\
\hline 07 & $0.0085(2)$ & $0.0132(2)$ & $0.00808(18)$ & 0 & $0.00007(16)$ & 0 \\
\hline 08 & $0.0090(2)$ & $0.0268(3)$ & $0.0153(2)$ & 0 & 0.00839 (17) & 0 \\
\hline$O 9$ & $0.0155(2)$ & $0.0234(3)$ & $0.00773(18)$ & 0 & 0.00601 (17) & 0 \\
\hline$O 10$ & 0.00779 (18) & $0.00623(16)$ & $0.01001(17)$ & 0 & 0.00517 (14) & 0 \\
\hline$H$ & $0.0244(5)$ & $0.0229(5)$ & $0.0168(4)$ & 0 & $0.0101(4)$ & 0 \\
\hline$T 848 \mathrm{~K}$ & $U_{11}$ & $U_{22}$ & $U_{33}$ & $U_{23}$ & $U_{13}$ & $U_{12}$ \\
\hline$A 1$ & $0.0348(5)$ & $0.0211(5)$ & $0.0231(4)$ & 0 & $0.0193(4)$ & 0 \\
\hline$A 2$ & $0.0181(3)$ & $0.0270(4)$ & $0.0158(3)$ & 0 & $0.0052(2)$ & 0 \\
\hline Si1 & 0.0108 (3) & $0.0126(3)$ & $0.0116(3)$ & 0 & 0.0037 (2) & 0 \\
\hline $\mathrm{Si} 2$ & $0.0104(3)$ & $0.0122(3)$ & $0.0125(3)$ & 0 & $0.0050(2)$ & 0 \\
\hline Si3 & $0.0095(3)$ & $0.0128(3)$ & $0.0115(3)$ & 0 & $0.0052(2)$ & 0 \\
\hline$M 1$ & $0.0142(3)$ & $0.0125(3)$ & $0.0160(3)$ & $-0.0009(2)$ & $0.0058(2)$ & $-0.0011(2)$ \\
\hline$M 2$ & $0.0107(3)$ & $0.0102(3)$ & $0.0142(3)$ & $-0.0005(3)$ & $0.0052(3)$ & -0.0001 \\
\hline$M 3$ & $0.01354(18)$ & $0.0217(2)$ & 0.01874 (19) & 0 & $0.00322(14)$ & 0 \\
\hline$O 1$ & $0.01783(18)$ & 0.01489 (19) & $0.0299(2)$ & $0.00234(18)$ & $0.01151(16)$ & $0.00302(16)$ \\
\hline$O 2$ & $0.01825(18)$ & $0.0202(2)$ & 0.02199 (19) & $-0.00320(17)$ & 0.00927 (15) & $-0.00670(17)$ \\
\hline$O 3$ & 0.01549 (18) & $0.01384(18)$ & $0.0218(2)$ & $-0.00174(16)$ & $0.00040(16)$ & $0.00216(16)$ \\
\hline$O 4$ & $0.0147(2)$ & $0.0161(3)$ & $0.0153(2)$ & 0 & $0.0050(2)$ & 0 \\
\hline 05 & $0.0169(3)$ & $0.0190(3)$ & $0.0119(2)$ & 0 & $0.0036(2)$ & 0 \\
\hline$O 6$ & $0.0185(2)$ & 0.0139 (2) & 0.0199 (2) & 0 & 0.01406 (19) & 0 \\
\hline$O 7$ & $0.0168(3)$ & $0.0302(4)$ & $0.0151(3)$ & 0 & $0.0005(2)$ & 0 \\
\hline 08 & 0.0157 (3) & $0.0510(6)$ & $0.0273(3)$ & 0 & $0.0137(2)$ & 0 \\
\hline 09 & $0.0330(4)$ & $0.0450(6)$ & $0.0142(3)$ & 0 & $0.0129(3)$ & 0 \\
\hline$O 10$ & $0.0168(2)$ & $0.0138(2)$ & $0.0198(2)$ & 0 & $0.0110(2)$ & 0 \\
\hline$H$ & $0.0451(9)$ & $0.0382(9)$ & $0.0298(7)$ & 0 & $0.0199(6)$ & 0 \\
\hline$T 1023 \mathrm{~K}$ & $U_{11}$ & $U_{22}$ & $U_{33}$ & $U_{23}$ & $U_{13}$ & $U_{12}$ \\
\hline$A 1$ & $0.053(2)$ & $0.0315(19)$ & $0.0409(19)$ & 0 & $0.0306(15)$ & 0 \\
\hline$A 2$ & $0.0352(13)$ & $0.0401(16)$ & 0.0337 (13) & 0 & $0.0165(10)$ & 0 \\
\hline$S i 1$ & $0.0223(13)$ & $0.0263(14)$ & $0.0292(14)$ & 0 & $0.0125(11)$ & 0 \\
\hline $\mathrm{Si} 2$ & $0.0231(13)$ & $0.0235(14)$ & $0.0282(13)$ & 0 & $0.0132(10)$ & 0 \\
\hline Si3 & $0.0243(12)$ & $0.0241(14)$ & $0.0284(13)$ & 0 & $0.0158(10)$ & 0 \\
\hline$M 1$ & $0.0305(12)$ & $0.0231(11)$ & $0.0325(12)$ & $-0.0009(10)$ & $0.0144(9)$ & $-0.0017(10)$ \\
\hline$M 2$ & $0.0240(14)$ & $0.0229(15)$ & $0.0308(16)$ & $0.0001(15)$ & $0.0119(12)$ & $0.0024(15)$ \\
\hline
\end{tabular}


Table 4 (continued)

\begin{tabular}{|c|c|c|c|c|c|c|}
\hline$T 1023 \mathrm{~K}$ & $U_{11}$ & $U_{22}$ & $U_{33}$ & $U_{23}$ & $U_{13}$ & $U_{12}$ \\
\hline M3 & $0.0266(8)$ & $0.0363(10)$ & $0.0370(10)$ & 0 & $0.0124(7)$ & 0 \\
\hline$O 1$ & $0.0322(8)$ & $0.0268(8)$ & $0.0513(10)$ & $0.0013(8)$ & $0.0226(7)$ & $0.0029(7)$ \\
\hline$O 2$ & $0.0337(8)$ & $0.0335(10)$ & $0.0408(9)$ & $-0.0034(8)$ & $0.0204(6)$ & $-0.0082(8)$ \\
\hline$O 3$ & $0.0297(8)$ & $0.0259(8)$ & $0.0401(9)$ & $-0.0009(8)$ & $0.0089(7)$ & $0.0029(7)$ \\
\hline$O 4$ & $0.0280(11)$ & $0.0257(11)$ & $0.0338(12)$ & 0 & $0.0133(9)$ & 0 \\
\hline 05 & $0.0303(12)$ & $0.0337(13)$ & $0.0276(11)$ & 0 & $0.0112(9)$ & 0 \\
\hline 06 & $0.0322(10)$ & $0.0285(11)$ & $0.0363(11)$ & 0 & $0.0232(8)$ & 0 \\
\hline 07 & $0.0308(13)$ & $0.0456(17)$ & $0.0331(13)$ & 0 & $0.0089(10)$ & 0 \\
\hline 08 & $0.0316(12)$ & $0.067(2)$ & $0.0497(16)$ & 0 & $0.0267(11)$ & 0 \\
\hline$O 9$ & 0.0535 (17) & $0.062(2)$ & $0.0317(12)$ & 0 & $0.0262(12)$ & 0 \\
\hline$O 10$ & $0.0321(11)$ & $0.0260(11)$ & $0.0397(12)$ & 0 & $0.0219(9)$ & 0 \\
\hline$H$ & $0.058(4)$ & $0.052(4)$ & $0.048(4)$ & 0 & $0.028(3)$ & 0 \\
\hline
\end{tabular}

M3 site, at $1023 \mathrm{~K}$, the fraction of Fe differs by $7 \sigma$ from that obtained at the lower temperatures, with a slight decrease of the Fe fraction (i.e. $83 \%$ vs. $90 \%$ ). A potential $T$-induced Fe migration (and fractionation) to the other octahedral $M 1$ and $M 2$ sites is possible (as observed at high $T$ even by Bonazzi and Menchetti 1994, by ex situ experiments), but the refinement at $1023 \mathrm{~K}$ does not reveal this behaviour at a significant level.

One of the additional main effect of temperature on the crystal structure of allanite is represented by the variation of the (anisotropic) displacement parameters magnitude, as shown in Fig. 3 and in Tables 4 and 5, which are expected to be realistic when obtained by neutron diffraction. The calculated root-means-square displacement amplitudes $(R M S)$, expressed in $\AA$ in Table 5, show an average increase of $\sim 50 \%$ between 293 and $848 \mathrm{~K}$, which rises to $100 \%$ between 293 and $1023 \mathrm{~K}$. However, the anisotropic scheme of the ellipsoids, expressed by the $R M S_{\max } / R M S_{\min }$ ratio in Table 5, is almost kept with increasing temperature, with a slight decrease of the anisotropy. The most pronounced ellipticity is observed for the $O 8$ and $O 9$ sites (i.e. respectively, with $R M S_{\max } / R M S_{\min }$ of 2.27 and 1.89 at $293 \mathrm{~K}$, and 1.80 and 1.65 at $1023 \mathrm{~K}$ ). The displacement of $O 8$ reflects its complex bonding configuration: it is the bridging site between $S i 2$ and $M 3$, and is also bonded to two independent $A 2$ sites. The multi-elemental populations at the $M 3$ site (with $\mathrm{Al}$ and $\mathrm{Fe}$ ) and at the $A 2$ site ( $\mathrm{Ca}$ and $\mathrm{REE}$ ) is expected to generate a static disorder at the $O 8$ site, with a resulting pronounced displacement parameter. Similar considerations can be extended to the $O 9$ site: it is the bridging oxygen between $\mathrm{Si} 1$ and $\mathrm{Si2}$, and is even bonded to two independent $A 1$ sites, having at least a bi-elemental population $(\mathrm{Ca}$ and Mn, along with Fe).

The neutron diffraction data allow us even to describe the effect of temperature on the H-bonding configuration in the structure of allanite. As for epidote sensu stricto, even in allanite there is only one unique $\mathrm{H}$-bond with an energetically favourable configuration, involving $O 10$ as a donor and $\mathrm{O} 4$ as an acceptor (i.e. O10-H...O4). According to Kvick et al. (1988) and Gatta et al. (2010), the deviation of the $\mathrm{O}_{\text {donor }}-\mathrm{H} \cdots \mathrm{O}_{\text {acceptor }}$ angle from the linearity (i.e. $\left.180^{\circ}\right)$ is likely ascribable to the electrostatic repulsion generated by trivalent cations at the $M 3$ and $A 2$ sites (at $293 \mathrm{~K}$ in this study: $M 3 \ldots H \sim 2.778(2)$ and $A 2 . . H 1 \sim 3.042(5) \AA$ ). In allanite, the $O 10-H \ldots O 4$ angle at $293 \mathrm{~K}$ is $169.4(1)^{\circ}$. The almost linear hydrogen bond in zoisite at $15 \mathrm{~K}$ (with $O 10-H \ldots O 4=176.4(2)^{\circ}, O 10 \cdots O 4=2.742(2) \AA$ and $H \cdots O 4=1.752(2) \AA$, Smith et al. 1988), corroborates that the presence of $\mathrm{Fe}^{3+}$ at $M 3$ leads to a weakening of the bonds, as reflected by the increase of the $\mathrm{O}_{\text {donor }} \ldots \mathrm{O}_{\text {acceptor }}$ and $\mathrm{H} . . \mathrm{O}_{\text {acceptor }}$ distances. Beyond the $T$-induced increase of the displacement ellipsoid magnitude, previously described, the effect of temperature does not change significantly the geometry of the bonding scheme, and no other acceptors are involved in response to the applied $T$. However, some minor (but significant) changes are observable: between 293 and $1023 \mathrm{~K}$, the H...O4 distance increases (i.e. $+0.111 \AA$ ) with a compensational decrease of the $O 10-H$ distance (corrected for riding motion effect, i.e. $-0.025 \AA)$; the $\mathrm{O}_{\text {donor }} \cdots \mathrm{O}_{\text {acceptor }}$ distance (i.e. O10...O4) overall decreases $(-0.075 \AA)$ and the variation of the $O 10-H \ldots O 4$ angle is not significant (within the e.s.d.). Test refinements with site occupancy factor (s.o.f.) of the $\mathrm{H}$ site free to vary, based on the data at 293, 848 and $1023 \mathrm{~K}$, were performed (Table 3). At $293 \mathrm{~K}$, the s.o.f. is equal to 1.0 within $2 \sigma$. At $848 \mathrm{~K}$, the refinement converges either with the s.o.f. fixed to 1.0 or with the refined value of $0.96(1)$. At $1023 \mathrm{~K}$, the figure of merit is higher with a refined s.o.f. of $0.89(3)$, showing a significant deviation from the full occupancy. This finding supports a partial dehydroxylation effect, where charge balance is maintained by oxidation of ferrous to ferric iron, as observed in 
Table 5 Root-means-square displacement amplitudes $(R M S$, in $\AA$ ) for anisotropic atoms

\begin{tabular}{|c|c|c|c|c|}
\hline$T 293 \mathrm{~K}$ & $R M S_{\text {min }}$ & $R M S_{\mathrm{mid}}$ & $R M S_{\max }$ & $R M S_{\max } / R M S_{\min }$ \\
\hline$A 1$ & 0.081 & 0.092 & 0.130 & 1.61 \\
\hline$A 2$ & 0.087 & 0.101 & 0.110 & 1.27 \\
\hline Si1 & 0.074 & 0.079 & 0.080 & 1.08 \\
\hline $\mathrm{Si} 2$ & 0.070 & 0.076 & 0.083 & 1.19 \\
\hline Si3 & 0.062 & 0.077 & 0.080 & 1.29 \\
\hline$M 1$ & 0.070 & 0.078 & 0.090 & 1.29 \\
\hline$M 2$ & 0.062 & 0.064 & 0.085 & 1.36 \\
\hline M3 & 0.077 & 0.089 & 0.104 & 1.34 \\
\hline$O 1$ & 0.078 & 0.096 & 0.128 & 1.64 \\
\hline$O 2$ & 0.078 & 0.101 & 0.120 & 1.54 \\
\hline$O 3$ & 0.075 & 0.080 & 0.132 & 1.77 \\
\hline$O 4$ & 0.084 & 0.092 & 0.095 & 1.14 \\
\hline 05 & 0.081 & 0.097 & 0.099 & 1.23 \\
\hline O6 & 0.069 & 0.079 & 0.108 & 1.56 \\
\hline 07 & 0.077 & 0.115 & 0.119 & 1.55 \\
\hline 08 & 0.072 & 0.126 & 0.164 & 2.27 \\
\hline$O 9$ & 0.081 & 0.125 & 0.153 & 1.89 \\
\hline$O 10$ & 0.078 & 0.079 & 0.101 & 1.30 \\
\hline$H$ & 0.124 & 0.151 & 0.156 & 1.26 \\
\hline$T 848 \mathrm{~K}$ & $R M S_{\min }$ & $R M S_{\mathrm{mid}}$ & $R M S_{\max }$ & $R M S_{\max } / R M S_{\min }$ \\
\hline$A 1$ & 0.121 & 0.145 & 0.190 & 1.57 \\
\hline$A 2$ & 0.123 & 0.144 & 0.164 & 1.33 \\
\hline Si1 & 0.103 & 0.112 & 0.114 & 1.12 \\
\hline $\mathrm{Si} 2$ & 0.101 & 0.111 & 0.112 & 1.11 \\
\hline Si3 & 0.093 & 0.107 & 0.113 & 1.22 \\
\hline$M 1$ & 0.103 & 0.122 & 0.129 & 1.18 \\
\hline$M 2$ & 0.101 & 0.103 & 0.120 & 1.20 \\
\hline$M 3$ & 0.113 & 0.147 & 0.153 & 1.35 \\
\hline$O 1$ & 0.113 & 0.134 & 0.174 & 1.54 \\
\hline$O 2$ & 0.111 & 0.145 & 0.162 & 1.46 \\
\hline$O 3$ & 0.110 & 0.118 & 0.182 & 1.66 \\
\hline$O 4$ & 0.118 & 0.127 & 0.132 & 1.12 \\
\hline$O 5$ & 0.108 & 0.138 & 0.141 & 1.31 \\
\hline$O 6$ & 0.094 & 0.118 & 0.153 & 1.62 \\
\hline 07 & 0.107 & 0.164 & 0.174 & 1.62 \\
\hline 08 & 0.103 & 0.166 & 0.226 & 2.19 \\
\hline 09 & 0.105 & 0.182 & 0.212 & 2.02 \\
\hline$O 10$ & 0.111 & 0.118 & 0.144 & 1.30 \\
\hline$H$ & 0.160 & 0.195 & 0.212 & 1.33 \\
\hline$T 1023 \mathrm{~K}$ & $R M S_{\min }$ & $R M S_{\text {mid }}$ & $R M S_{\max }$ & $R M S_{\max } / R M S_{\min }$ \\
\hline$A 1$ & 0.164 & 0.178 & 0.237 & 1.45 \\
\hline$A 2$ & 0.177 & 0.190 & 0.200 & 1.13 \\
\hline Si1 & 0.144 & 0.162 & 0.171 & 1.19 \\
\hline $\mathrm{Si} 2$ & 0.143 & 0.153 & 0.169 & 1.18 \\
\hline Si3 & 0.134 & 0.155 & 0.173 & 1.29 \\
\hline$M 1$ & 0.151 & 0.172 & 0.181 & 1.20 \\
\hline$M 2$ & 0.143 & 0.161 & 0.176 & 1.23 \\
\hline M3 & 0.163 & 0.191 & 0.196 & 1.21 \\
\hline
\end{tabular}


Table 5 (continued)

\begin{tabular}{lllll}
\hline$T 1023 \mathrm{~K}$ & $R M S_{\min }$ & $R M S_{\operatorname{mid}}$ & $R M S_{\max }$ & $R M S_{\max } / R M S_{\min }$ \\
\hline$O 1$ & 0.156 & 0.172 & 0.227 & 1.45 \\
$O 2$ & 0.153 & 0.188 & 0.211 & 1.38 \\
$O 3$ & 0.156 & 0.173 & 0.218 & 1.40 \\
$O 4$ & 0.160 & 0.167 & 0.184 & 1.15 \\
$O 5$ & 0.166 & 0.178 & 0.184 & 1.12 \\
$O 6$ & 0.138 & 0.169 & 0.201 & 1.46 \\
$O 7$ & 0.169 & 0.201 & 0.214 & 1.26 \\
$O 9$ & 0.143 & 0.226 & 0.258 & 1.80 \\
$H$ & 0.151 & 0.232 & 0.249 & 1.65 \\
\hline
\end{tabular}

E.s.d. on the last digit

previous ex situ experiments (e.g. Dollase 1973; Bonazzi and Menchetti 1994), according to:

$$
{ }^{M 3} \mathrm{Fe}^{2+}+{ }^{O 10} \mathrm{OH}^{-} \rightarrow{ }^{M 3} \mathrm{Fe}^{3+}+{ }^{O 10} \mathrm{O}^{2-}+1 / 2 \mathrm{H}_{2} .
$$

\section{Discussion and conclusions}

To the best of our knowledge, this is the first study on the thermal expansion of allanite described on the basis of in situ experiments, aimed to provide the thermo-elastic parameters of this mineral and the description of the $T$-induced structural rearrangement at the atomic scale. The experimental findings of this study confirm that allanite preserves its crystallinity at least up to $1073 \mathrm{~K}$, but behaves elastically likely up to $700 \mathrm{~K}$ (Fig. 2, Table 7). Other sorosilicates investigated at high temperature, by in situ X-ray or neutron diffraction experiments, do not show deviation from the elastic behaviour within the $T$-range investigated (e.g. up to $1173 \mathrm{~K}$ for clinozoisite, Pawley et al. 1996; 1023 K for zoisite, Cámara et al. 2012; $1170 \mathrm{~K}$ for epidote, Gatta et al. 2011), even up to $T$-induced breakdown (i.e. $1150-1200 \mathrm{~K}$ for strontian piemontite, Catti et al. 1988).

The volume thermal expansion coefficient of allanite (at room conditions), valid within its elasticity window, is $\alpha_{\mathrm{T} 0}(V)=2.8(3) \times 10^{-5} \mathrm{~K}^{-1}$. Using the same calculation protocol here adopted for allanite (with the mHP-EoS), the coefficients obtained on the basis of the clinozoisite (Pawley et al. 1996) and epidote (Gatta et al. 2011) data are virtually identical: $\alpha_{\mathrm{T} 0}(V)=2.9(3) \times 10^{-5} \mathrm{~K}^{-1}$ for clinozoisite and $\alpha_{\mathrm{T} 0}(V)=2.8(2) \times 10^{-5} \mathrm{~K}^{-1}$ for epidote. We cannot exclude that a better precision and accuracy of the data would unveil modest, but significant, differences. Conversely, the (isothermal) bulk compression of these three sorosilicates is significantly different: using a third-order Birch-Murnaghan EoS, the bulk modulus of allanite is $K_{\mathrm{P} 0, \mathrm{~T} 0}=131(4) \mathrm{GPa}$ $\left(K_{\mathrm{P} 0, \mathrm{~T} 0} \equiv 1 / \beta_{\mathrm{P} 0, \mathrm{~T} 0}\right)$ and its $P$-derivative is $K^{\prime}=1.9(8)(\mathrm{Gatta}$ et al. 2019), $K_{\mathrm{P} 0, \mathrm{~T} 0}=111(3) \mathrm{GPa}$ and $K^{\prime}=7.6(7)$ for epidote with $0.74 \mathrm{Fe}$ a.p.f.u. (Gatta et al. 2011) and $K_{\mathrm{P} 0, \mathrm{~T} 0}=115(2)$ $\mathrm{GPa}$ and $K^{\prime}=3.7(2)$ for epidote with $0.79 \mathrm{Fe}$ a.p.f.u. (Qin et al. 2016), and $K_{\mathrm{P} 0, \mathrm{~T} 0}=142(3) \mathrm{GPa}$ and $K^{\prime}=5.2(4)$ for clinozoisite with $0.40 \mathrm{Fe}$ a.p.f.u. (Qin et al. 2016). Epidote is, therefore, the softest member, clinozoisite is the stiffest and allanite lies in between. Comparing the compressional paths of epidotes with different $\mathrm{Fe}$ fraction and clinozoisite, Qin et al. (2016) argued how the increasing content of Fe reduces the bulk modulus and increases the first $P$-derivative, ascribing such a behaviour to the differences in compression in response to the addition of $\mathrm{Fe}$ at the $M 3$ site (replacing $\mathrm{Al}$ ). As discussed by Gatta et al. (2019), the conclusion of Qin et al (2016), confined to the epidote-clinozoisite join, cannot be simplistically extended to allanite, as more variables influence the different behaviour of this mineral: $\mathrm{Fe}$ and $\mathrm{Al}$ mainly populate at least two octahedral sites (and not only one, as in epidote), and $\mathrm{Fe}$ occurs in two different oxidation numbers; $\mathrm{Fe}, \mathrm{Mn}$ along with a series of other LREE elements (mainly $\mathrm{La}, \mathrm{Ce}$, and $\mathrm{Nd}$ ) replace $\mathrm{Ca}$ at the $A 1$ and $A 2$ sites; the $A 2$ site can be partially populated, etc.. 
Table 6 Relevant bond distances $(\AA)$ and angles $\left(^{\circ}\right)$ in allanite structure at different temperatures

\begin{tabular}{|c|c|c|c|c|c|}
\hline & $293 \mathrm{~K}$ & $848 \mathrm{~K}$ & & $1023 \mathrm{~K}$ & \\
\hline $\mathrm{Si} 1-\mathrm{O} 1 \times 2$ & $1.6382(6)$ & $1.6391(8)$ & [1.6468] & $1.645(3)$ & [1.653] \\
\hline Si1-O7 & $1.5880(10)$ & $1.588(1)$ & [1.5982] & $1.574(5)$ & [1.586] \\
\hline $\mathrm{Si} 1-\mathrm{O9}$ & $1.6470(9)$ & $1.649(1)$ & [1.6649] & $1.639(5)$ & [1.657] \\
\hline $\mathrm{Si} 2-\mathrm{O} 3 \times 2$ & $1.6274(6)$ & $1.6304(8)$ & [1.6377] & $1.638(3)$ & [1.647] \\
\hline $\mathrm{Si} 2-\mathrm{O} 8$ & $1.5948(9)$ & $1.597(1)$ & [1.6141] & $1.586(5)$ & [1.606] \\
\hline $\mathrm{Si} 2-\mathrm{O} 9$ & $1.6347(10)$ & $1.634(1)$ & [1.6502] & $1.631(5)$ & [1.651] \\
\hline $\mathrm{Si} 3-\mathrm{O} 2 \times 2$ & $1.6259(6)$ & $1.6289(8)$ & [1.6371] & $1.634(3)$ & [1.645] \\
\hline $\mathrm{Si3}-\mathrm{O} 5$ & $1.6572(9)$ & $1.657(1)$ & [1.6627] & $1.654(5)$ & [1.661] \\
\hline Si3-O6 & $1.6449(8)$ & $1.651(1)$ & [1.6552] & $1.646(4)$ & [1.652] \\
\hline$M 1-O 4 \times 2$ & $1.8674(4)$ & $1.8692(6)$ & [1.8703] & $1.872(2)$ & {$[1.872 *]$} \\
\hline$M 1-O 1 \times 2$ & $1.9771(4)$ & $1.9900(7)$ & [1.9945] & $1.999(2)$ & [2.002] \\
\hline$M 1-O 5 \times 2$ & $2.0028(4)$ & $2.0201(6)$ & [2.0218] & $2.030(2)$ & [2.030] \\
\hline$M 2-O 3 \times 2$ & $1.8654(4)$ & $1.8723(7)$ & [1.8786] & $1.874(2)$ & [1.879] \\
\hline$M 2-O 6 \times 2$ & $1.9212(3)$ & $1.9374(7)$ & [1.9402] & $1.950(2)$ & [1.952] \\
\hline$M 2-O 10 \times 2$ & $1.9003(4)$ & $1.9055(6)$ & [1.9086] & $1.907(2)$ & [1.909] \\
\hline$M 3-O 1 \times 2$ & $2.2752(5)$ & $2.3018(9)$ & [2.3026] & $2.310(3)$ & [2.311] \\
\hline$M 3-O 2 \times 2$ & $2.1651(5)$ & $2.1823(8)$ & [2.1827] & $2.176(3)$ & [2.177] \\
\hline$M 3-O 4$ & $1.9741(7)$ & $1.968(1)$ & [1.9657] & $1.962(4)$ & [1.959] \\
\hline$M 3-O 8$ & $1.9480(8)$ & $1.944(1)$ & [1.9524] & $1.936(4)$ & [1.944] \\
\hline$A 1-O 1 \times 2$ & $2.3804(8)$ & $2.395(1)$ & & $2.402(4)$ & \\
\hline$A 1-O 3 \times 2$ & 2.3394 (7) & $2.359(1)$ & & $2.362(4)$ & \\
\hline$A 1-O 5$ & $2.5814(11)$ & $2.604(2)$ & & $2.606(6)$ & \\
\hline$A 1-O 6$ & $2.8920(11)$ & $2.892(2)$ & & $2.892(6)$ & \\
\hline$A 1-O 7$ & $2.3447(11)$ & $2.362(2)$ & & $2.370(6)$ & \\
\hline$A 1-O 9 \times 2$ & $3.0941(5)$ & 3.104 (1) & & 3.105 (3) & \\
\hline$A 2-O 2 \times 2$ & $2.4748(6)$ & 2.498 (1) & & 2.508 (3) & \\
\hline$A 2-O 2^{\prime} \times 2$ & $2.6578(7)$ & $2.672(1)$ & & $2.692(4)$ & \\
\hline$A 2-O 3 \times 2$ & $2.7658(7)$ & $2.773(1)$ & & $2.766(3)$ & \\
\hline$A 2-O 7$ & $2.3074(9)$ & 2.315 (1) & & $2.323(5)$ & \\
\hline$A 2-O 10$ & $2.5995(9)$ & $2.619(1)$ & & $2.605(4)$ & \\
\hline$A 2-O 8 \times 2$ & 3.0057 (3) & $3.024(1)$ & & $3.034(2)$ & \\
\hline$O 10-H$ & $0.986(2)$ & $0.973(2)$ & & $0.950(9)$ & \\
\hline$O 10-H^{\mathrm{RM}}$ & 1.003 & 1.001 & & 0.978 & \\
\hline$O 10 \ldots O 4$ & 2.908 (1) & $2.956(1)$ & & $2.983(5)$ & \\
\hline H...O4 & $1.933(2)$ & $1.994(3)$ & & $2.044(10)$ & \\
\hline$O 10-H \ldots O 4$ & $169.4(1)$ & $168.9(2)$ & & $169.6(7)$ & \\
\hline Si2-O9-Si1 & $145.56(7)$ & $146.34(9)$ & & $147.5(3)$ & \\
\hline$O 6 \leftrightarrow O 10$ & $7.022(3)$ & 7.068 (17) & & $7.064(33)$ & \\
\hline$O 3 \leftrightarrow O 3$ & 7.267 (4) & $7.314(22)$ & & $7.341(45)$ & \\
\hline$O 6 \leftrightarrow 06$ & $7.686(3)$ & 7.729 (17) & & $7.716(35)$ & \\
\hline $08 \leftrightarrow 08$ & $4.751(1)$ & $4.828(5)$ & & $4.887(9)$ & \\
\hline$O 3 \leftrightarrow O 1$ & $3.621(0)$ & $3.645(3)$ & & $3.656(5)$ & \\
\hline$O 6 \leftrightarrow O 1$ & $4.378(5)$ & $4.385(26)$ & & $4.400(52)$ & \\
\hline$O 9 \leftrightarrow O 5$ & $4.670(1)$ & $4.690(4)$ & & $4.682(8)$ & \\
\hline
\end{tabular}

In the squared brackets: bond distances corrected for "rigid body motion" following Downs et al. (1992) and Downs (2000); "O10$H^{R M}$ ": bond distance corrected for "riding motion" following Busing and Levy (1964). Principal "diameters" (§) of the 8-membered ring $(O 6 \leftrightarrow O 10, O 3 \leftrightarrow 03, O 6 \leftrightarrow O 6$ and $O 8 \leftrightarrow O 8)$ and of the 5-membered one $(O 3 \leftrightarrow O 1, O 6 \leftrightarrow O 1, O 9 \leftrightarrow 05)$ at different temperatures are also given

*Correction for "rigid body motion" not applicable
The thermo-elastic anisotropy of the allanite here investigated is modest along the three principal crystallographic axes, being $\alpha_{\mathrm{T} 0}(a): \alpha_{\mathrm{T} 0}(b): \alpha_{\mathrm{T} 0}(c)=1.08: 1: 1.36$, but not if we consider magnitude and orientation of the unit-strain ellipsoid, being $\varepsilon 1: \varepsilon 2: \varepsilon 3=2.57: 1.61: 1$ (with $\varepsilon 2 / /[010], \varepsilon 1$ and $\varepsilon 3$ dispersed in the (010)-plane, $\left.\varepsilon 1 \angle[100]=42.2(5)^{\circ}\right)$. At high pressure, the compressional anisotropy of allanite along the three main crystallographic directions is: $\beta_{\mathrm{P} 0, \mathrm{~T} 0}(a): \beta_{\mathrm{P} 0, \mathrm{~T} 0}(b): \beta_{\mathrm{P} 0, \mathrm{~T} 0}(c)=1.23: 1: 1.52$ (recalculated from Gatta et al. 2019). The unit-strain ellipsoid at high pressure is oriented with the mid axis $(\varepsilon 2)$ parallel to the $b$-axis, and the major $(\varepsilon 1)$ and minor $(\varepsilon 3)$ axes lying in the (010)-plane, with $\varepsilon 1: \varepsilon 2: \varepsilon 3=2.18: 1.47: 1$ and $\varepsilon 1 \angle[100]=136.6(2)^{\circ}$ (or $43.4(2)^{\circ}$ from $a$, for an easier comparison with the $\mathrm{H} T$ data of this study). These experimental findings show that:

- Among the three main crystallographic directions, the minimum expansion and compression occurs along [010];

- However, [010] is not the least expandable or stiffest direction of the structure, as shown by the thermal and compressional unit-strain ellipsoids. The least expandable and stiffest directions, along with the most expandable and softest directions, lie in the (010) plane.

To extend our comparative analysis to epidote $(0.74 \mathrm{Fe}$ a.p.f.u., Gatta et al. 2011) and clinozoisite (0.02 Fe a.p.f.u., Holland et al. 1996; Pawley et al. 1996), we have recalculated magnitude and orientation of their unit-strain ellipsoids up to $c a .700 \mathrm{~K}$, adopting the same protocol here applied to allanite. For both epidote and clinozoisite, $\varepsilon 2 / /[010], \varepsilon 1$ and $\varepsilon 3$ are dispersed in the (010) plane, with $\varepsilon 1 \angle[100]=57.9(6)^{\circ}$ in epidote and $\varepsilon 1 \angle[100]=55(3)^{\circ}$ in clinozoisite. There is a consistent orientation of the ellipsoids among the three sorosilicates, with a slightly lower $\varepsilon 1 \angle[100]$ angle in allanite. This finding suggests that there must be a strong control of the structure topology on the thermal anisotropy, otherwise the three sorosilicates should experience a different anisotropic scheme.

The data on allanite show that the inter- and intra-polyhedral mechanisms, described on the basis of the structure refinements at high temperature, are not sufficient to explain, unambiguously, the magnitude and orientation of the $\mathrm{HT}$ unit-strain ellipsoid. It is predictable that the [010] direction cannot be the most expandable one, as the expansion of the structure along this direction is hindered by the presence of the (infinite) edge-sharing $M 1 \mathrm{O}_{6}$ octahedral chains, running along [010] and acting as "pillars", so that extension along the chain can only take place through polyhedral expansion (i.e. bond distances extension). On the other hand, it is not trivial to enucleate, on the (010) plane, the reasons for the minor and major expansion 

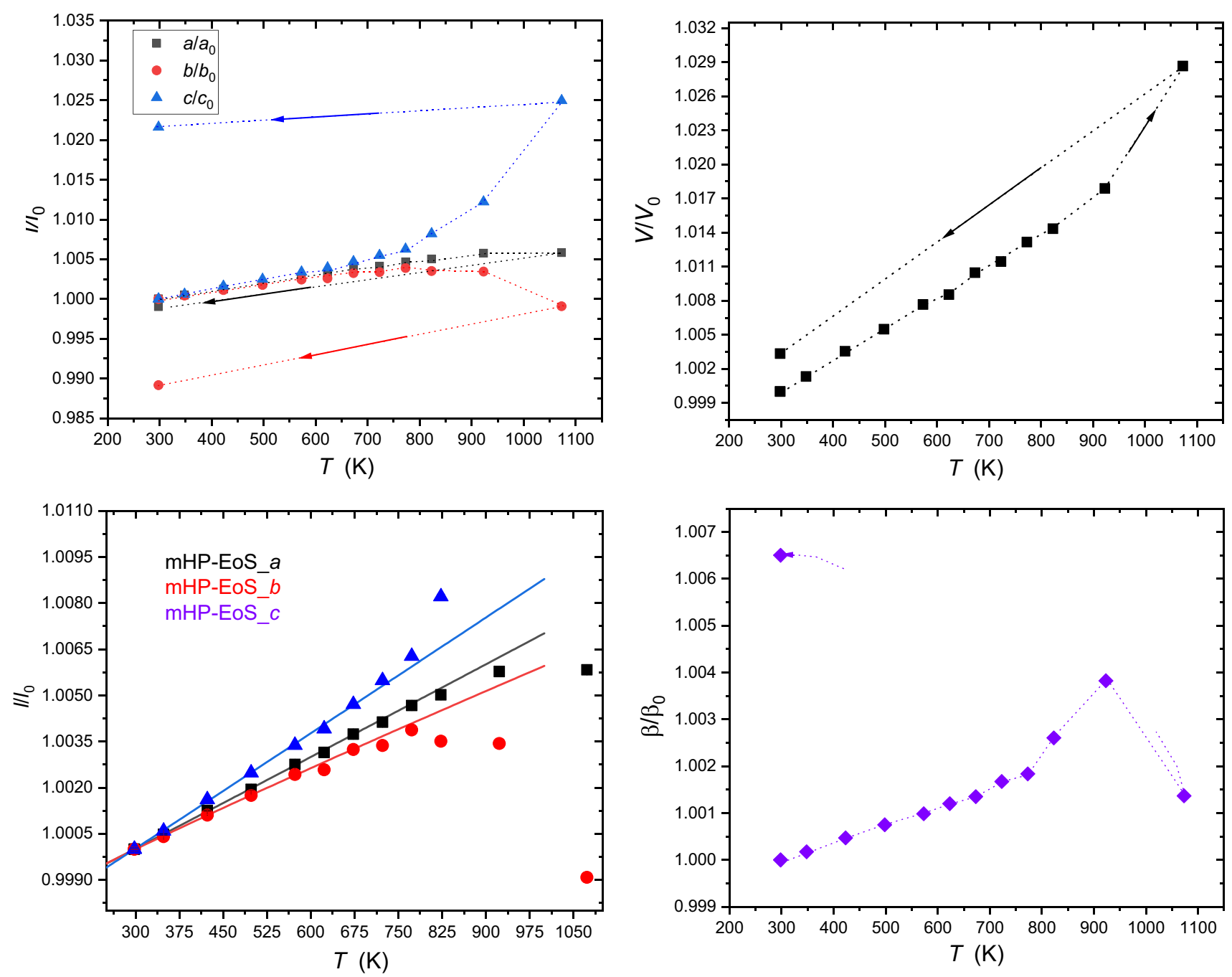

Fig. 2 Evolution of the lattice parameters of allanite, normalised to the room $T$ values, with $T$. Error bars are shorter than the size of the symbols. Dotted lines are guide for the eye. Solid lines represent the

modified Holland-Powell Equation of State fit (mHP-EoS) to the experimental data, ranging between the elasticity windows: 293$700 \mathrm{~K}$ (zoom diagram, bottom left)

directions, which are likely the effect of a complex combination of inter-polyhedral tilting and intra-polyhedral (expansion + distortion), along with cation migration and partial dehydroxylation. Furthermore, it is worth to consider that the $\mathrm{H} T$ structure refinements of this study are based on data collected out of the elasticity window (i.e. $T>700 \mathrm{~K}$ ), whereas the elastic parameters (along with magnitude and orientation of the unit-strain ellipsoid) are valid within the elasticity window (i.e. 293-700 K).

The ex situ high- $T$ experiments on allanite reported by Bonazzi and Menchetti (1994), based on single-crystal X-ray

diffraction data, showed how crystals annealed in air for $48 \mathrm{~h}$ at several temperatures, ranging between 653 and $1173 \mathrm{~K}$, experienced a significant change of the unit-cell parameters, coupled with relevant structure rearrangements. In particular, in the treated allanite, it was observed an irreversible shortening of the unit-cell edges along $a$ and $b$, coupled with a lengthening along $c$ and an increase of the monoclinic $\beta$ angle value. The structure refinements of the treated crystals proved a $T$-induced oxidation-dehydroxylation/dehydrogenation process, with the mechanism described in the previous section, coupled with a modest migration of octahedral 
Table 7 Unit-cell parameters of allanite with $T$, based on two independent in situ synchrotron X-ray diffraction ramps (*data collected after the HT ramp)

\begin{tabular}{llllll}
\hline Ramp_1 & $a(\AA)$ & $b(\AA)$ & $c(\AA)$ & $\beta\left({ }^{\circ}\right)$ & $V\left(\AA^{3}\right)$ \\
$293 \mathrm{~K}$ & $8.8990(2)$ & $5.7248(1)$ & $10.1081(2)$ & $114.837(2) 467.33(1)$ \\
348 & $8.9033(2)$ & $5.7272(1)$ & $10.1141(2)$ & $114.857(2) 467.95(1)$ \\
423 & $8.9102(2)$ & $5.7312(1)$ & $10.1244(2)$ & $114.891(2) 468.99(1)$ \\
498 & $8.9163(2)$ & $5.7349(1)$ & $10.1332(2)$ & $114.923(2) 469.90(1)$ \\
573 & $8.9235(2)$ & $5.7388(1)$ & $10.1423(2)$ & $114.950(2) 470.91(1)$ \\
673 & $8.9323(2)$ & $5.7434(1)$ & $10.1557(2)$ & $114.992(2) 472.22(1)$ \\
773 & $8.9406(2)$ & $5.7471(1)$ & $10.1715(2)$ & $115.048(2) 473.48(1)$ \\
923 & $8.9504(5)$ & $5.7445(2)$ & $10.2314(4)$ & $115.276(4) 475.69(3)$ \\
1073 & $8.9509(4)$ & $5.7196(2)$ & $10.3602(3)$ & $114.994(4) 480.72(3)$ \\
Ramp_2 & & & & \\
$293 \mathrm{~K}$ & $8.9038(6)$ & $5.7269(4)$ & $10.1188(6)$ & $114.841(6) 468.24(3)$ \\
623 & $8.9318(5)$ & $5.7417(3)$ & $10.1584(6)$ & $114.979(5) 472.23(3)$ \\
723 & $8.9406(6)$ & $5.7462(3)$ & $10.1743(6)$ & $115.033(6)$ & $473.60(3)$ \\
823 & $8.9485(3)$ & $5.7470(4)$ & $10.2019(8)$ & $115.140(8)$ & $474.95(4)$ \\
$293 *$ & $8.8951(11)$ & $5.6648(7)$ & $10.337(1)$ & $115.59(1) 469.80(6)$ \\
\hline
\end{tabular}

cations (deduced on the basis of the refined electron density at the $M$ sites). Fe-oxidation generates mainly a shortening of the M3-O distances, along with a minor contraction of the $M 1-\mathrm{O}$ distances, a pronounced lengthening of the $\mathrm{O}_{\text {donor }} . \mathrm{O}_{\text {acceptor }}$ distance with a compensational shortening of the $\mathrm{O} 10-\mathrm{H}$ distance. The experimental data of the in situ $\mathrm{HT}$ experiments of this study cannot be directly compared with the ex situ data of Bonazzi and Menchetti (1994), but the trends observed in both these studies are comparable. Even the in situ experiment of this study shows that, at $T$ higher than the elasticity window (i.e.>700 K), an inversion of the (ordinary) positive expansion path is observed along the $a$ and $b$ axes (more pronounced along $b$ ) and for
Table 8 Thermo-elastic parameters of allanite up to $c a .700 \mathrm{~K}$, obtained by the (modified) Holland-Powell Equation of State fit to the experimental data (see text for details)

\begin{tabular}{ll}
\hline Unit-cell volume & \\
$\alpha_{0}\left(\times 10^{5} \mathrm{~K}^{-1}\right)$ & $2.7(8)$ \\
$\alpha_{1}\left(\times 10^{4} \mathrm{~K}^{-1 / 2}\right)$ & $-2.8(9)$ \\
$\alpha_{\mathrm{T} 0}(V)\left(\times 10^{5} \mathrm{~K}^{-1}\right)$ & $2.8(3)$ \\
$V_{\mathrm{T} 0}\left(\AA^{3}\right)$ & $467.33(6)$ \\
$a$ axis & \\
$\alpha_{0}\left(\times 10^{5} \mathrm{~K}^{-1}\right)$ & $1.1(2)$ \\
$\alpha_{1}\left(\times 10^{4} \mathrm{~K}^{-1 / 2}\right)$ & $-0.9(2)$ \\
$\alpha_{\mathrm{T} 0}(a)\left(\times 10^{5} \mathrm{~K}^{-1}\right)$ & $0.98(9)$ \\
$a_{\mathrm{T} 0}(\AA)$ & $8.8990(3)$ \\
$b$ axis & \\
$\alpha_{0}\left(\times 10^{5} \mathrm{~K}^{-1}\right)$ & $0.7(2)$ \\
$\alpha_{1}\left(\times 10^{4} \mathrm{~K}^{-1 / 2}\right)$ & $-1.1(2)$ \\
$\alpha_{\mathrm{T} 0}(b)\left(\times 10^{5} \mathrm{~K}^{-1}\right)$ & $0.91(7)$ \\
$b_{\mathrm{T} 0}(\AA)$ & $5.7247(2)$ \\
$c$ axis & \\
$\alpha_{0}\left(\times 10^{5} \mathrm{~K}^{-1}\right)$ & $1.3(2)$ \\
$\alpha_{1}\left(\times 10^{4} \mathrm{~K}^{-1 / 2}\right)$ & $-1.2(3)$ \\
$\alpha_{\mathrm{T} 0}(c)\left(\times 10^{5} \mathrm{~K}^{-1}\right)$ & $1.24(9)$ \\
$c_{\mathrm{T} 0}(\AA)$ & $10.1081(4)$ \\
\hline$P a r 9$ &
\end{tabular}

Parameters refined using the experimental data weighted by their uncertainties and normalised to their respective ambient- $T$ values

the monoclinic $\beta$ angle, whereas an anomalous increase of the expansion is observed along the $c$ axis. Less pronounced are the effects at the atomic scale, likely because the in situ experiment does not reach the same oxidation-dehydroxylation level as that of the ex situ experiments of Bonazzi and Menchetti (1994).
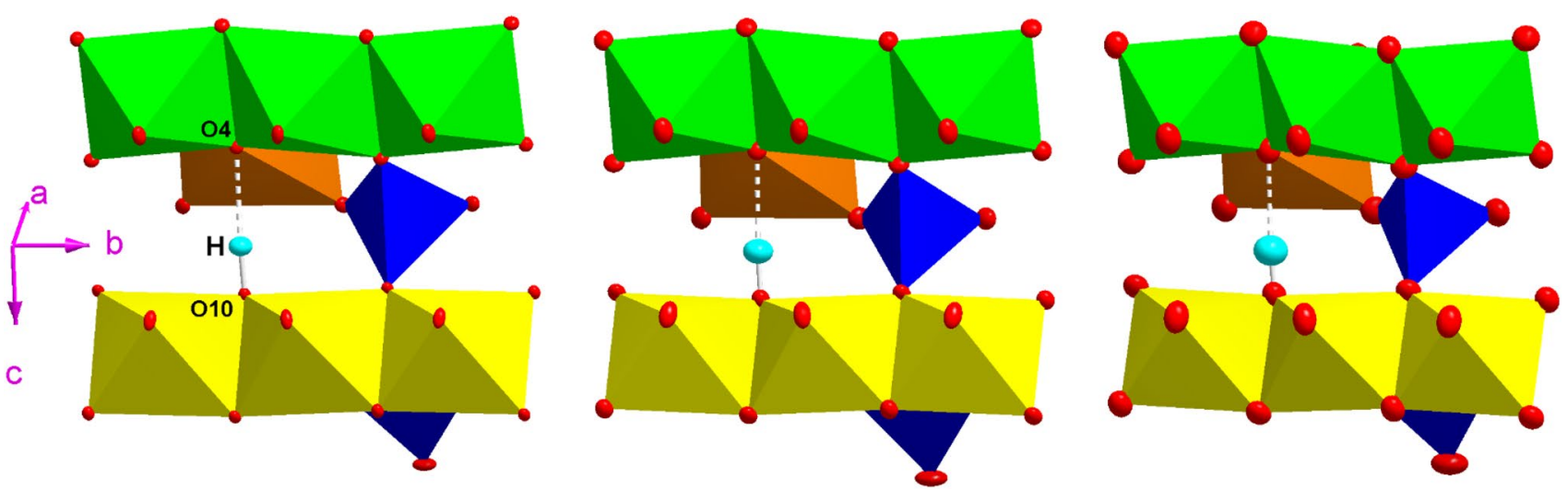

Fig. 3 H-bonding scheme and evolution of the atomic displacement parameters with $T$ (from left to right: at 293, 848, and 1023 K). Displacement ellipsoids drawn at the 50\% probability level. Colour details in Fig. 1 
Acknowledgements ELETTRA (Basovizza, Trieste, Italy) and ILL (Grenoble, France, metadata repository, https://doi.org/10.5291/ ILL-DATA.EASY-658) are acknowledged for provision of beamtime. G.D.G., F.P. and P.L. acknowledge the support of the Italian Ministry of Education (MIUR) through the project "Dipartimenti di Eccellenza 2018-2022". G.D.G. and P.L. acknowledge the support of the University of Milano through the project "Piano di Sostegno alla Ricerca 2019". The authors thank two anonymous reviewers and the editor C. McCammon for the revision of the manuscript. This paper is dedicated to Friedrich A. Seifert (b. 1941), Professor emeritus, BGI-Universität Bayreuth, on the occasion of his 80th birthday.

Funding Open access funding provided by Università degli Studi di Milano within the CRUI-CARE Agreement.

Open Access This article is licensed under a Creative Commons Attribution 4.0 International License, which permits use, sharing, adaptation, distribution and reproduction in any medium or format, as long as you give appropriate credit to the original author(s) and the source, provide a link to the Creative Commons licence, and indicate if changes were made. The images or other third party material in this article are included in the article's Creative Commons licence, unless indicated otherwise in a credit line to the material. If material is not included in the article's Creative Commons licence and your intended use is not permitted by statutory regulation or exceeds the permitted use, you will need to obtain permission directly from the copyright holder. To view a copy of this licence, visit http://creativecommons.org/licenses/by/4.0/.

\section{References}

Angel RJ, Alvaro M, Gonzalez-Platas J (2014) EosFit7c and a Fortran module (library) for equation of state calculations. Z Kristallogr Cryst Mater 229:405-419

Armbruster T, Bonazzi P, Akasaka M, Bermanec V, Chopin C, Gieré R, Heuss-Assbichler S, Liebscher A, Menchetti S, Pan Y, Pasero M (2006) Recommended nomenclature of epidote-group minerals. Eur J Mineral 18:551-567

Bird DK, Helgeson HC (1980) Chemical interaction of aqueous solutions with epidote-feldspar mineral assemblages in geologic systems, I: thermodynamic analysis of phase relations in the system $\mathrm{CaO}-\mathrm{FeO}-\mathrm{Fe}_{2} \mathrm{O}_{3}-\mathrm{Al}_{2} \mathrm{O}_{3}-\mathrm{SiO}_{2}-\mathrm{H}_{2} \mathrm{O}-\mathrm{CO}_{2}$. Am J Science 280:907-941

Bird DK, Cho M, Janik CJ, Liou JG, Caruso LJ (1988) Compositional, order-disorder, and stable isotopic characteristics of Al-Fe epidote, state 2-14 drill hole, Salton Sea geothermal system. J Geophys Res 93(B11):13135-13144

Bonazzi P, Menchetti S (1994) Structural variations induced by heat treatment in allanite and REE-bearing piemontite. Am Mineral 79:1176-1184

Bonazzi P, Menchetti S (1995) Monoclinic members of the epidote group: effect of the $\mathrm{Al} \leftrightarrow \mathrm{Fe}^{3+} \leftrightarrow \mathrm{Fe}^{2+}$ substitution and of the entry of $\mathrm{REE}^{3+}$. Mineral Petrol 53:133-153

Bonazzi P, Holtstam D, Bindi L, Nysten P, Capitani GC (2009) Multi-analytical approach to solve the puzzle of an allanitesubgroup mineral from Kesebol, Västra Götaland, Sweden. Am Mineral 94:121-134

Cámara F, Gatta GD, Meven M, Pasqual D (2012) Thermal expansion and high temperature structure evolution of zoisite by single-crystal X-ray and neutron diffraction. Phys Chem Minerals 39:27-45

Carswell DA, Wilson RN, Zhai M (2000) Metamorphic evolution, mineral chemistry and thermobarometry of schists and orthogneisses hosting ultra-high pressure eclogites in the Dabieshan of central China. Lithos 52:121-155

Catti M, Ferraris G, Ivaldi G (1988) Thermal behaviour of the crystal structure of strontian piemontite. Am Mineral 73:1370-1376

Comodi P, Zanazzi PF (1997) The pressure behaviour of clinozoisite and zoisite. An X-ray diffraction study. Am Mineral 82:61-68

Corti L, Zanoni D, Gatta GD, Zucali M (2020) Strain partitioning in host rock controls light rare earth element release from allanite(Ce) in subduction zones. Mineral Mag 84:93-118

Dal Piaz G (1975) Angelo Bianchi. La val Devero ed i suoi minerali. Memorie Istituto Geologia Università Padova, allegato Volume X, Società Cooperativa, Tipografica, Padova, Italy

Dollase WA (1971) Refinement of the crystal structure of epidote, allanite and hancockite. Am Mineral 56:447-464

Dollase WA (1973) Mössbauer spectra and iron distribution in the epidote-group minerals. Z Kristallogr 138:41-63

Downs RT (2000) Analysis of harmonic displacement factors. In: Hazen RM, Downs RT (eds) High-temperature and high-pressure crystal chemistry. Reviews in Mineralogy and Geochemistry, Mineralogical Society of America and Geochemical Society, vol 41, Washington, pp 61-117

Downs RT, Gibbs GV, Bartelmehs KL, Boisen MB Jr (1992) Variations of bond lengths and volumes of silicate tetrahedra with temperature. Am Mineral 77:751-757

Duisenberg AJM (1992) Indexing in single-crystal diffractometry with an obstinate list of reflections. J Appl Cryst 25:92-96

Franz G, Liebscher A (2004) Physical and chemical properties of epidote minerals - an introduction. In: Franz G, Liebscher A (eds) Epidotes. Reviews in Mineralogy and Geochemistry, Mineralogical Society of America and Geochemical Society, vol 56, Washington, USA, pp 1-81

Gatta GD, Meven M, Bromiley G (2010) Effects of temperature on the crystal structure of epidote: a neutron single-crystal diffraction study at 293 and 1,070 K. Phys Chem Minerals 37:475-485

Gatta GD, Merlini M, Lee Y, Poli S (2011) Behavior of epidote at high pressure and high temperature: a powder diffraction study up to 10 GPa and 1,200 K. Phys Chem Minerals 38:419-428

Gatta GD, Alvaro M, Bromiley G (2012) A low temperature X-ray single-crystal diffraction and polarised infra-red study of epidote. Phys Chem Minerals 39:1-15

Gatta GD, Milani S, Corti L, Comboni D, Lotti P, Merlini M, Liermann H-P (2019) Allanite at high pressure: effect of REE on the elastic behaviour of epidote-group minerals. Phys Chem Minerals 46:783-793

Gieré R, Sorensen SS (2004) Allanite and other REE-rich epidotegroup minerals. In: Franz G, Liebscher A (eds) Epidotes. Reviews in Mineralogy and Geochemistry, Mineralogical Society of America and Geochemical Society, vol 56, Washington, USA, pp 431-493

Gonzalez-Platas J, Alvaro M, Nestola F, Angel RJ (2016) EosFit7-GUI: a new graphical user interface for equation of state calculations, analyses and teaching. J Appl Cryst 49:1377-1382

Gromet LP, Silver LT (1983) Rare earth element distributions among minerals in a granodiorite and their petrogenetic implications. Geochim Cosmochim Acta 47:925-940

Guastoni A, Pezzotta F, Vignola P (2006) Characterization, paragenesis and genetic inferences of arsenates, sulfates and vanadates of $\mathrm{Fe}$, $\mathrm{Cu}, \mathrm{Pb}, \mathrm{Zn}$ from Mount Cervandone (Western Alps, Italy). Period Mineral 76:141-150

Hermann J (2002) Allanite: thorium and light rare earth element carrier in subducted crust. Chem Geol 192:289-306

Holdaway MJ (1972) Thermal stability of Al-Fe epidotes as a function of $f \mathrm{O}_{2}$ and $\mathrm{Fe}$ content. Contrib Min Petrol 37:307-340 
Holland TJB, Powell R (1998) An internally consistent thermodynamic data set for phases of petrological interest. J Metamorph Geol 16:309-343

Holland TJB, Redfern SAT, Pawley AR (1996) Volume behaviour of hydrous minerals at high pressure and temperature: II. Compressibilities of lawsonite, zoisite, clinozoisite, and epidote. Am Mineral 81:341-348

Klemd R (2004) Fluid inclusions in epidote minerals and fluid development in epidote-bearing rocks. In: Franz G, Liebscher A (eds) Epidotes. Reviews in Mineralogy and Geochemistry, Mineralogical Society of America and Geochemical Society, vol 56, Washington, USA, pp 197-234

Kvick $\AA$, Pluth JJ, Richardson JW Jr, Smith JV (1988) The ferric ion distribution and hydrogen bonding in epidote: a neutron diffraction study at $15 \mathrm{~K}$. Acta Cryst B44:351-355

Larson AC (1967) Inclusion of secondary extinction in least-squares calculations. Acta Cryst 23:664-665

Larson AC, Von Dreele RB (2004) General structure analysis system (GSAS), Los Alamos National Laboratory Report LAUR, pp $86-748$

Li B, Xu J, Zhang D, Ye Z, Huang S, Fan D, Zhou W, Xie H (2021) Thermoelasticity and stability of natural epidote at high pressure and high temperature: implications for water transport during cold slab subduction. Geosci Front 12:921-928

Liebscher A (2004) Spectroscopy of epidote minerals. In: Franz G, Liebscher A (eds) Epidotes. Reviews in Mineralogy and Geochemistry, Mineralogical Society of America and Geochemical Society, vol 56, Washington, USA, pp 125-170

Liou JG (1973) Synthesis and stability relations of epidote, $\mathrm{Ca}_{2} \mathrm{Al}_{2} \mathrm{FeSi}_{3} \mathrm{O}_{12}(\mathrm{OH})$. J Petrol 14:381-413

Matthewman JC, ThompsonP BPJ (1982) The Cambridge crystallography subroutine library. J Appl Cryst 15:167-173

McIntyre GJ, Stansfield RFD (1988) A general Lorentz correction for single-crystal diffractometers. Acta Cryst A44:257-262

Pawley AR, Redfern SAT, Holland TJB (1996) Volume behaviour of hydrous minerals at high pressure and temperature: 1 . Thermal expansion of lawsonite, zoisite, clinozoisite, and diaspore. Am Mineral 81:335-340

Poli S, Schmidt MW (1998) The high-pressure stability of zoisite and phase relationships of zoisite-bearing assemblages. Contrib Mineral Petrol 130:162-175

Qin F, Wu X, Wang Y, Fan D, Qin S, Yang K, Townsend JP, Jacobsen SD (2016) High-pressure behavior of natural single-crystal epidote and clinozoisite up to $40 \mathrm{GPa}$. Phys Chem Minerals 43:649-659
Rebuffi L, Plaisier JR, Abdellatief M, Lausi A, Scardi P (2014) MCX: a synchrotron radiation beamline for $\mathrm{X}$-ray diffraction line profile analysis. Z Anorg Allg Chem 640:3100-3106

Sawka WN, Chappell BW, Norrish K (1984) Light-rare-earth element zoning in sphene and allanite during granitoid fractionation. Geology 12:131-134

Schmidt MW, Poli S (2004) Magmatic epidotes. In: Franz G, Liebscher A (eds) Epidotes. Reviews in Mineralogy and Geochemistry, Mineralogical Society of America and Geochemical Society, vol 56, Washington, pp 399-430

Sears VF (1986) Neutron scattering lengths and cross-sections. In: Sköld K, Price DL (eds) Neutron scattering, methods of experimental physics, 23A. Academic Press, Cambridge, pp 521-550

Sheldrick GM (1997) SHELX-97. Programs for crystal structure determination and refinement. University of Göttingen, Germany

Sheldrick GM (2008) A short history of SHELX. Acta Cryst A64:112-122

Sheldrick GM (2015) Crystal structure refinement with SHELXL. Acta Cryst C71:3-8

Smith JV, Pluth JJ, Richardson JW Jr, Kvick Å (1988) Neutron diffraction study of zoisite at $15 \mathrm{~K}$ and X-ray study at room temperature. Z Kristallogr 179:305-321

Sorensen SS (1991) Petrogenetic significance of zoned allanite in garnet amphibolites from a paleo-subduction zone: Catalina Schist, southern California. Am Mineral 76:589-601

Thompson P, Cox DE, Hastings JB (1988) Rietveld refinement of DebyeScherrer synchrotron X-ray data from $\mathrm{Al}_{2} \mathrm{O}_{3}$. J Appl Cryst 20:79-83

Toby BH (2001) EXPGUI, a graphical user interface for GSAS. J Appl Cryst 34:210-213

Tribuzio R, Messiga B, Vannucci R, Bottazzi P (1996) Rare earth element redistribution during high-pressure low-temperature metamorphism in ophiolitic Fe-gabbros (Liguria, northwestern Italy): implications for light REE mobility in subduction zones. Geology 24:711-714

Wilkinson C, Khamis HW, Stansfield RFD, McIntyre GJ (1988) Integration of single-crystal reflections using area multidetectors. J Appl Cryst 21:471-478

Publisher's Note Springer Nature remains neutral with regard to jurisdictional claims in published maps and institutional affiliations. 